\title{
Chemical composition of Lake Orta sediments
}

\author{
Renato BAUDO* and Monica BELTRAMI \\ CNR Istituto Italiano di Idrobiologia, Largo V. Tonolli 50, 28922 Verbania Pallanza, Italy \\ *e-mail corresponding author: r.baudo@iii.to.cnr.it
}

\begin{abstract}
Lake Orta $\left(18.2 \mathrm{~km}^{2}, 1.3 \mathrm{~km}^{3}, 143 \mathrm{~m}\right.$ max. depth) has been severely polluted since industrialisation of its watershed began in 1926, at which time the lake began to receive industrial effluents containing high concentrations of copper and ammonia. Chromium-, nickel-, and zinc-rich effluents from plating factories have also contributed to pollution levels, and pH -levels dropped below 4.0 as a result of the oxidation of ammonia to nitrates. More than 60 papers have documented the evolution of the chemical characteristics of both water and sediment, and the sudden decline of plankton, as well as benthos and fish. As a remedial action the lake was limed from May 1989 to June 1990 with 10,900 tons of $\mathrm{CaCO}_{3}$. The treatment was immediately effective in raising the pH and decreasing the metal concentrations in the water column, and plankton and fish communities quickly rebounded. However, the chemical characteristics of sediments were influenced by the liming to a much lesser extent. Since 900 tons of copper and the same amount of chromium were contained in the top $10 \mathrm{~cm}$ of sediment, it appears likely that the sediment could potentially act as a current and future source of these metals to the water column. This observation has resulted in the implementation of a vigorous monitoring regime to track the post-liming recovery of Lake Orta.
\end{abstract}

Key words: metals, sediments, chemistry, Lake Orta

\section{INTRODUCTION}

Lake Orta (Fig. 1) belongs to the Italian sub-alpine lake district and it is the seventh largest Italian lake with respect to volume and depth. It was formed by glacial erosion of a former river valley during the Mediterranean salinity crisis that occurred in the Messinian period. The lake has an altitude of $290 \mathrm{~m}$ a.s.l., with long and narrow shape stretched from North to South, and is fed by six main tributaries which account for approximately $76 \%$ of the lake's watershed. All of these tributaries lie on the eastern side of the lake, with the exception of the River Pescone, which lies on Orta's western shore.

The drainage basin of Lake Orta consists mainly of gneiss, mica schist, and granites (Boriani \& Sacchi 1974; Fig. 2). The highest point in the watershed is 1643 $\mathrm{m}$ a.s.l. while the average altitude is $590 \mathrm{~m} \mathrm{a.s.1}$. (Carollo \& Libera 1990).

The first studies on the pelagic fauna date back to the last century (Pavesi 1877; 1879a; 1879b), and shown a diversified phytoplankton community (Parona 1880; Bonardi 1885; Giaj-Levra 1925), with as many as 154 different species of diatoms. This high level of diversity was similar to that found in the other subalpine lakes (Parona 1880; Bonardi 1885; Giaj-Levra 1925). Zooplankton assemblages also indicated oligotrophic conditions (Bonacina et al. 1988a), and the abundant fish stock sustained an intensive fishery (Pavesi 1986; Monti 1929). However, the lake has been polluted since 1926 having received industrial effluents which are rich in copper and ammonium sulphate from a factory producing artificial silk by means of the cuproammonia method. This factory is located on the Southern shore of the lake, opposite the lake outlet, which lies at Orta's northern end.

These polluting discharges immediately affected the lake biocenosis: by 1927 a rapid decline of the phytoplankton was observed, followed by that of zooplankton and fish fauna, such that in only three years (Monti 1930) the lake was considered to be "sterile". The toxic effect was initially due to the increase of copper concentrations in the waters, reaching a peak of $100 \mu \mathrm{g}^{-1}$ in 1950 (Picotti 1958; Corbella et al. 1958; Tonolli \& Vollenweider 1961a, b).

The copper input dropped significantly in 1958 when the rayon factory installed a water treatment plant, but at the same time a number of electroplating factories began to discharge copper, zinc, nickel, and chromium into the lake (Bonacina 1970; Barbanti et al. 1972; Calamari \& Marchetti 1975). In the same period, the biochemical oxidation of ammonia (Vollenweider 1963), which was still being discharged at a high rate by the rayon factory, resulted in a progressive acidification of the waters due to proton production by two different mechanisms (Ruess 1975; van Breemen et al. 1984; Buysman et al. 1985). The first mechanism was the oxidation of ammonia to nitrates, producing two moles of $\mathrm{H}^{+}$and consuming two moles of $\mathrm{O}_{2}$, and the second was the assimilation of $\mathrm{NH}_{4}^{+}$by primary producers, accompanied by an equivalent release of protons (Goldman \& Brewer 1980; Raven 1985).

In Lake Orta these reactions were favoured by the low alkalinity (0.2-0.3 meq $\mathrm{l}^{-1}$; Monti 1930), and poor 

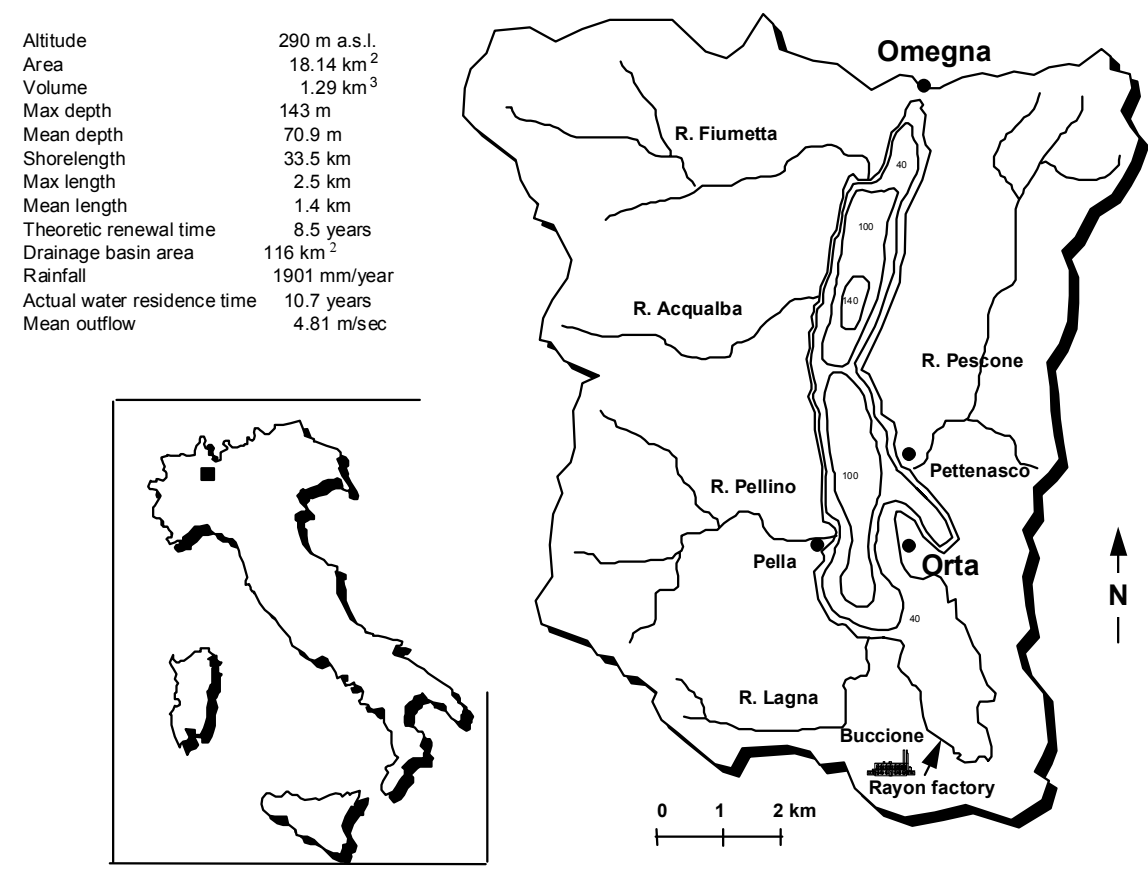

Fig. 1. Morphometric characteristics of the lake and its drainage basin.

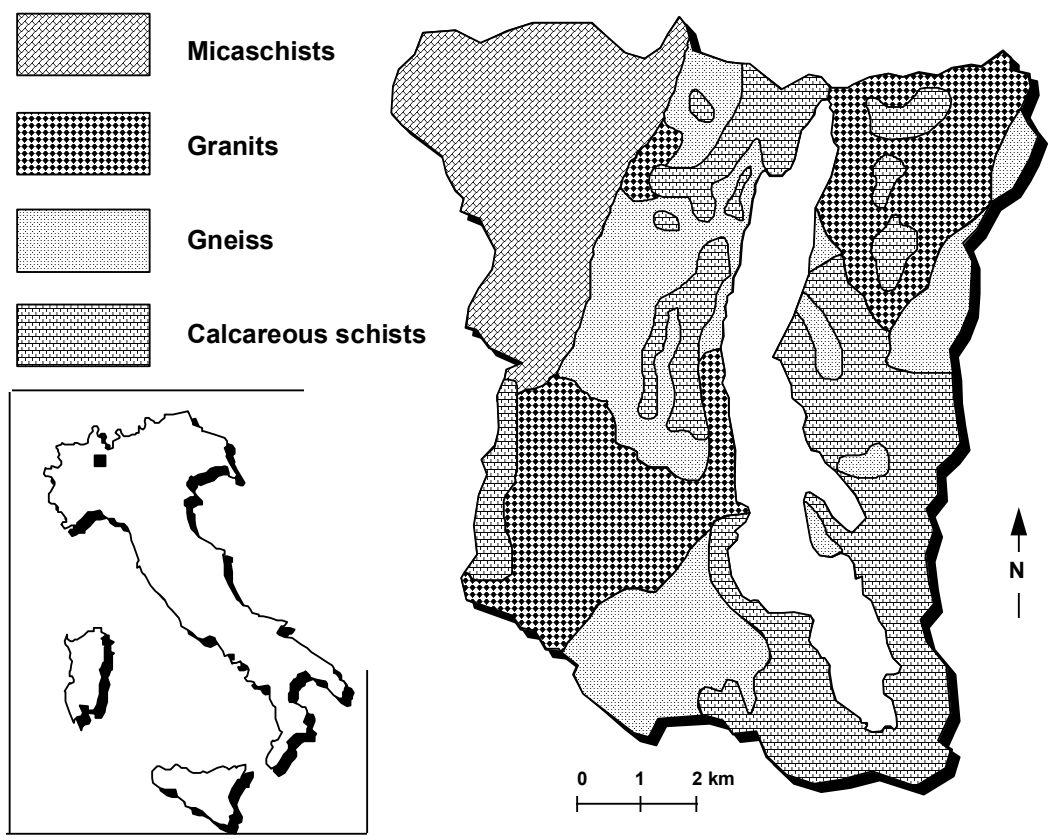

Fig. 2. Lithology of L. Orta watershed.

buffering capacity of the water, which comes from tributaries draining the silicious watershed. In the 1970s the $\mathrm{pH}$ of the water column dropped as low as $3.9-4.5$ (Bonacina \& Bonomi 1984), with a corresponding increase of nitrates. But at the beginning of the eighties a recovery phase began with the installation of a new treatment plant at the rayon factory in 1981, which further reduced copper loading from 4000 to $300 \mathrm{~kg} \mathrm{y}^{-1}$, and lowered ammonia loading by $95 \%$, from 3000 to 30 $\mathrm{t} \mathrm{N} \mathrm{y}^{-1}$. Water chemistry immediately responded to these changes (Mosello et al. 1986a, b; Bonacina et al. 1988a, b), and between February 1980 and February 1989 ammonia decreased from 5.1 to $1.2 \mathrm{mg} \mathrm{N}^{-1}$, and copper from 48 to $36 \mu \mathrm{g}^{-1}$.

However, the $\mathrm{pH}$ of the lake remained very acidic, though occasional $\mathrm{pH}$ increases in the epilimnion (6.0- 

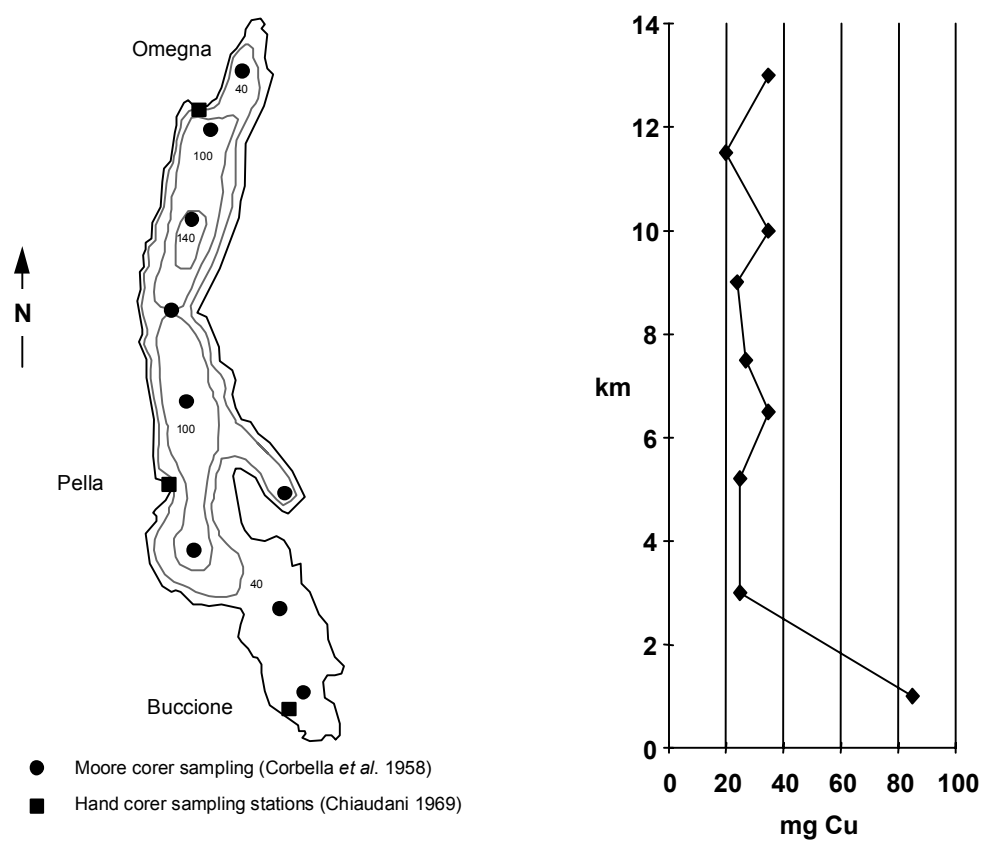

Fig. 3. Sediment sampling stations (Corbella et al. 1958; Chiaudani 1969) and copper concentration (mg Cu ml ${ }^{-1}$ wet sediment) in the first $6 \mathrm{~cm}$ of sediment as a function of the distance from the Southern shore of the lake.

$6.5 \mathrm{pH}$ units in September 1984) resulted from photosynthetic consumption of carbon dioxide (Mosello et al. 1986b). During these events, $\mathrm{Cu}$ and $\mathrm{Cr}$ decreased in the epilimnion due to co-precipitation with the hydrated oxides of $\mathrm{Al}$ and Fe (Mosello et al. 1986a), but metals levels were still high enough to be toxic to aquatic organisms (Barbanti et al. 1972; Gerletti \& Provini 1978; Mosello et al. 1986b; Calderoni et al. 1992). A chemical balance model was developed which incorporated current loadings from the watershed, indicating that a period of 15-20 years would be required for the lake to reach an alkalinity of $100-200$ meq $\mathrm{l}^{-1}$ (Mosello et al. 1986a, b; Mosello et al. 1989; Calderoni \& Mosello 1990). In order to expedite the recovery of the lake, it was proposed to treat the waters with calcium carbonate (Bonacina et al. 1987, 1988) until complete oxidation of ammonia was achieved and an alkalinity of at least 50 meq $\mathrm{l}^{-1}$ was attained (Calderoni et al. 1990).

The liming took place in 1989-1990 (Calderoni et al. 1991), and a total of $14,500 \mathrm{t}$ of limestone was ultimately used, increasing the $\mathrm{pH}$ to almost 6.0, and obtaining a reduction of the ammonia concentration down to $0.09 \mathrm{mg} \mathrm{N}^{-1}$, along with a severe drop in dissolved metal concentration. Plankton (Tondina 1992), littoral fauna (Ballarè et al. 1992) and fish fauna (Giussani 1990) quickly responded to the treatment, showing a good recovery both in size and quality. The evolution of the lake conditions during this period was also studied through the characterisation of the chemical composition of the sediments. It is well known that aquatic sediments tend to be contaminated by both inorganic and organic pollutants because the toxicants, once ad- sorbed or incorporated into the suspended particulate matter (biotic and/or abiotic), become deposited on the lake bottom, from which the solid/liquid equilibrium generally results in an enrichment in toxic elements and compounds in interstitial waters (Knight 1984; Cairns et al. 1984; Salomons et al. 1987; Tessier \& Campbell 1987; Chapman 1987).

\section{PRE-LIMING STUDIES}

In 1956 (Corbella et al. 1958; Tonolli \& Vollenweider 1961), samples were collected by means of a Moore corer in nine stations along the lake main axis (Fig. 3). These cores were sectioned into $1 \mathrm{~cm}$ layers, and dried at $60{ }^{\circ} \mathrm{C}$. Chlorophyll pigments were measured in all the samples by photometry at $675 \mathrm{~nm}$, following extraction with ethyl ether. Further aliquots of each sample were evaluated for dry weight and ash-free dry weight by heating at 105 and $600{ }^{\circ} \mathrm{C}$. A portion of the samples dried at $105{ }^{\circ} \mathrm{C}$ were also gravimetrically analysed for $\mathrm{Fe}, \mathrm{Al}$ and $\mathrm{Si}$, while copper was colorimetrically measured according to the sodium diethylditiocarbamate method (Picotti \& Baldassi 1941).

Both organic matter and chlorophyll pigments showed a peak around a sediment depth of 3-4 cm, in approximately the same location in which copper displayed a peak. The average concentration of copper in top sediments was $3542 \mathrm{mg} \mathrm{kg}^{-1}$ dry weight; this was thus interpreted as a massive sedimentation of plankton which had been killed by the metal. The intensity of this phenomenon diminishes with distance from the pollutant source. 


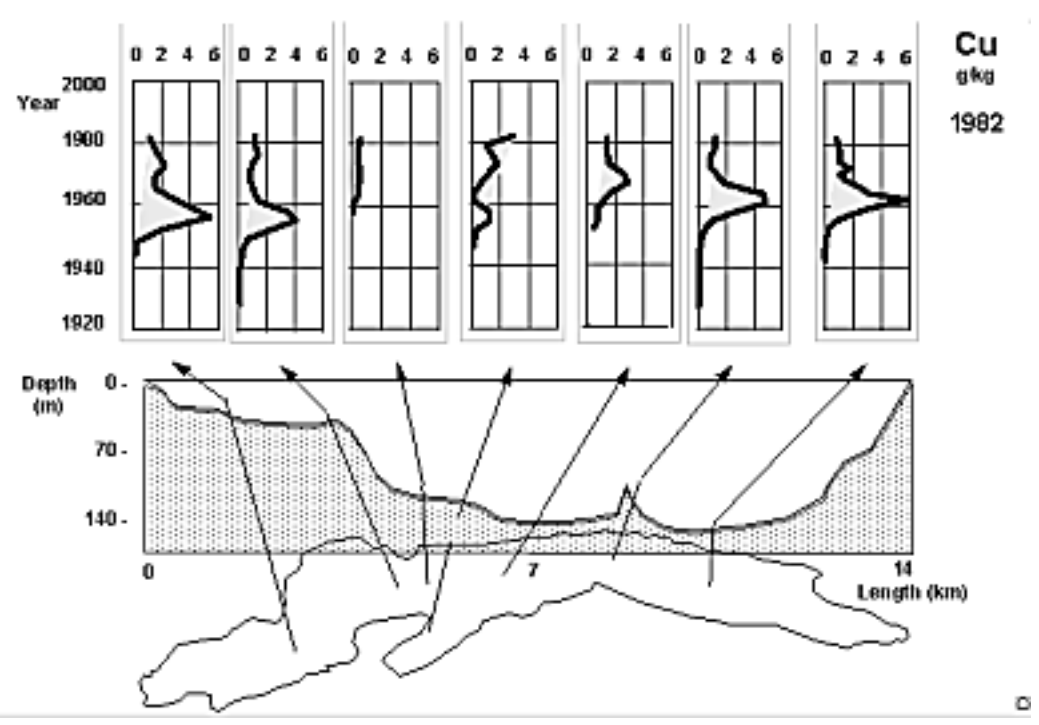

Fig. 4. $\mathrm{Cu}$ distribution $\left(\mathrm{g} \mathrm{kg}^{-1}\right)$ in cores collected in Lake Orta during 1982 (from data of Provini \& Gaggino 1985).

On the basis of these data, the sedimentation rate was calculated to be on the order of 30 to $40 \mathrm{~mm}$ in the previous thirty years (from the onset of the pollution to the time of sampling); and using the mean copper concentration in the top $6 \mathrm{~cm}$ layer, it can be estimated that as much as $23.8 \mathrm{~g} \mathrm{Cu}$ per square meter have been deposited.

Since natural input probably accounts only for $2.6 \mathrm{~g}$ $\mathrm{m}^{-2}$, about $380 \mathrm{t}$ of $\mathrm{Cu}$ have been incorporated into the sediment due to the industrial effluents. Significant and undefined amounts of the metal were still present into the waters of the lake, in its biotic components, or had left the lake through its outlet.

In 1969 (Chiaudani 1969), 3 sediment samples were collected within the reed stands of Omegna, Pella and Buccione (Fig. 3). The upper $20 \mathrm{~cm}$ of each sample were dried at $105^{\circ} \mathrm{C}$, homogenised, and sieved through a $2 \mathrm{~mm}$ mesh. One $\mathrm{g}$ of the sample was then extracted with warm perchloric acid, after oxidation of the organic matter with nitric acid, for the colorimetric determination of copper (sodium diethylditiocarbammate method, after Borchardt \& Butler 1957). On a separate aliquot of the sediment, the loss on ignition was measured by heating the material at $700{ }^{\circ} \mathrm{C}$ for 4 hours.

Copper concentrations of $215.5,210.5$ and $237.0 \mathrm{mg}$ $\mathrm{kg}^{-1}$ were found at Omegna, Pella and Buccione, respectively, with corresponding amounts of 4.91, 2.93 and $1.11 \%$ of organic matter. The metal concentrations in the littoral sediments were thus quite uniform, and far lower then in the deeper parts of the lake.

In 1978 (Guilizzoni 1978; Adams et al. 1978), a core was collected from the deepest point of Lake Orta by means of a freeze corer. The core was sectioned in 10 $\mathrm{cm}$ layers to measure sedimentary pigments (spectrophotometric method), and organic matter and calcium carbonates (gravimetrically). For phosphorus, the extraction method of Metha et al. (1954), followed by colorimetric determination (Murphy \& Riley 1962), was used.

Dating with ${ }^{137} \mathrm{Cs}$ indicated an annual sedimentation of $2 \mathrm{~mm} \mathrm{y}^{-1}$ or higher. The distribution profiles for organic matter, $\mathrm{CaCO}_{3}$ and sedimentary pigments confirmed the hypothesis of Corbella et al. (1958); i.e. that an increased sedimentation of phytoplanktonic remains exists in the surficial sediments due to industrial pollution. In fact, organic matter, as a percentage of dry weight, was almost constant at $10 \%$ between 10 and 90 $\mathrm{cm}$ of depth of sediment, but increased to $23 \%$ in the top layer.

In 1982 (Provini \& Gaggino 1985), 9 cores were collected (Fig. 4) with a Jenkin corer, divided into $1 \mathrm{~cm}$ layers, and dried at $105{ }^{\circ} \mathrm{C}$ for 24 hours. After grinding, aliquots of the samples were treated with a $1: 1$ mixture of perchloric and nitric acid at room temperature overnight, then autoclaved at $120{ }^{\circ} \mathrm{C}$ for 2 hours, and finally heated in a water bath at $80{ }^{\circ} \mathrm{C}$ for 5 hours (Julshamm \& Braekkan 1975). Concentrations of $\mathrm{Cu}, \mathrm{Cr}$ and $\mathrm{Zn}$ in the resulting solutions were measured by flame atomic absorption spectrometry. In four of these cores, ${ }^{137} \mathrm{Cs}$ was measured for dating of the sediments.

In the first three centimetres of sediments, between 1 and $4 \mathrm{mg} \mathrm{g}^{-1}$ of $\mathrm{Cu}, 1-2.7 \mathrm{mg} \mathrm{g}^{-1} \mathrm{Cr}$, and $0.3-1.5 \mathrm{mg} \mathrm{g}^{-1}$ of $\mathrm{Zn}$ were measured. Since the sedimentation rate ranged from 0.24 to $0.45 \mathrm{~cm} \mathrm{y}^{-1}$, it has been estimated that the copper peak dated back to 1955, and, after a sharp decrease, the concentration increased again in the sixties, when $\mathrm{Cr}$ and $\mathrm{Zn}$ also reached their peaks.

In 1982 around $4 \mathrm{t} \mathrm{y}^{-1} \mathrm{Cu}$ were deposited, and since 1927 as much as $560 \mathrm{t} \mathrm{Cu}, 380 \mathrm{t} \mathrm{Cr}$, and $30 \mathrm{t} \mathrm{Zn}$ have become incorporated into the sediments. 

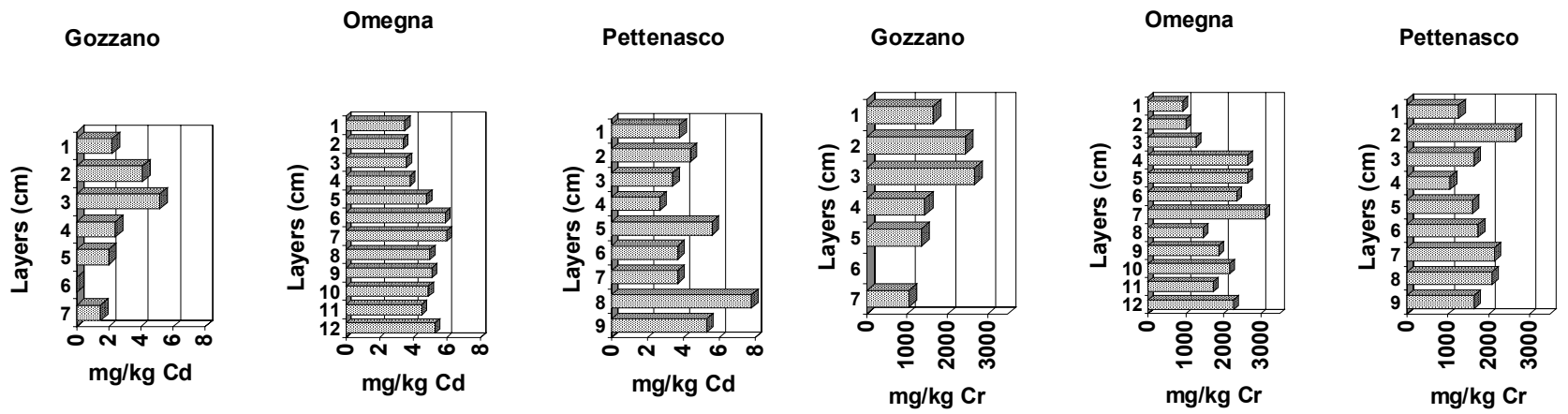

Fig. 5. Cd profiles $\left(\mathrm{mg} \mathrm{kg}^{-1}\right)$. For each core, the deepest layers date back to 1954 (from the data of Provini et al. 1987).

Fig. 6. Cr profiles $\left(\mathrm{mg} \mathrm{kg}^{-1}\right)$. For each core, the deepest layers date back to 1954 (from the data of Provini et al. 1987).
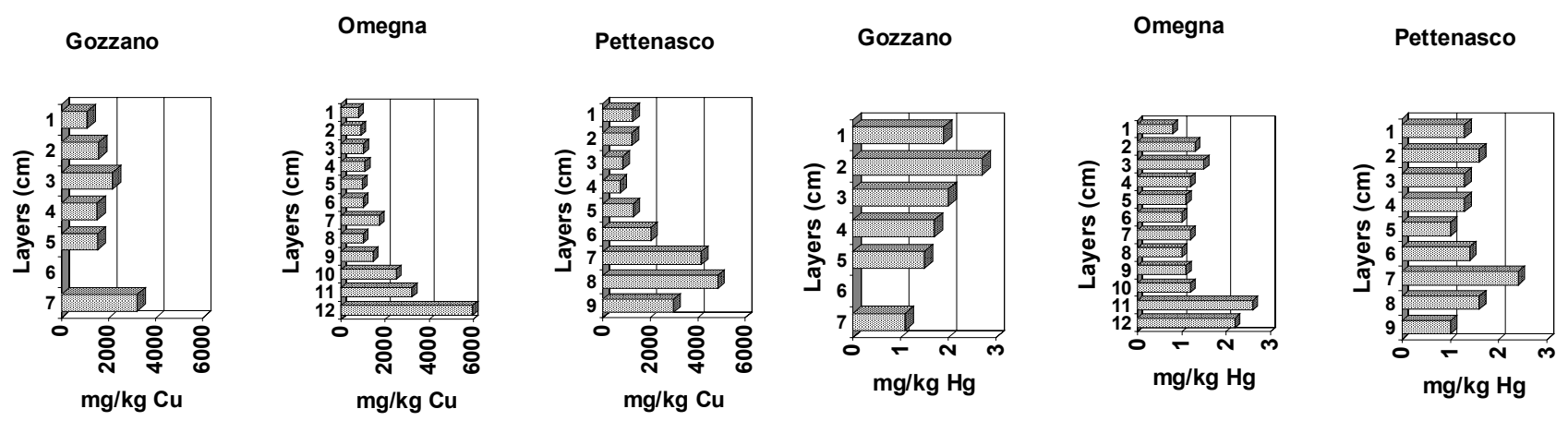

Fig. 7. $\mathrm{Cu}$ profiles $\left(\mathrm{mg} \mathrm{kg}^{-1}\right)$. For each core, the deepest layers date back to 1954 (from the data of Provini et al. 1987).

Fig. 8. $\mathrm{Hg}$ profiles $\left(\mathrm{mg} \mathrm{kg}^{-1}\right)$. For each core, the deepest layers date back to 1954 (from the data of Provini et al. 1987).
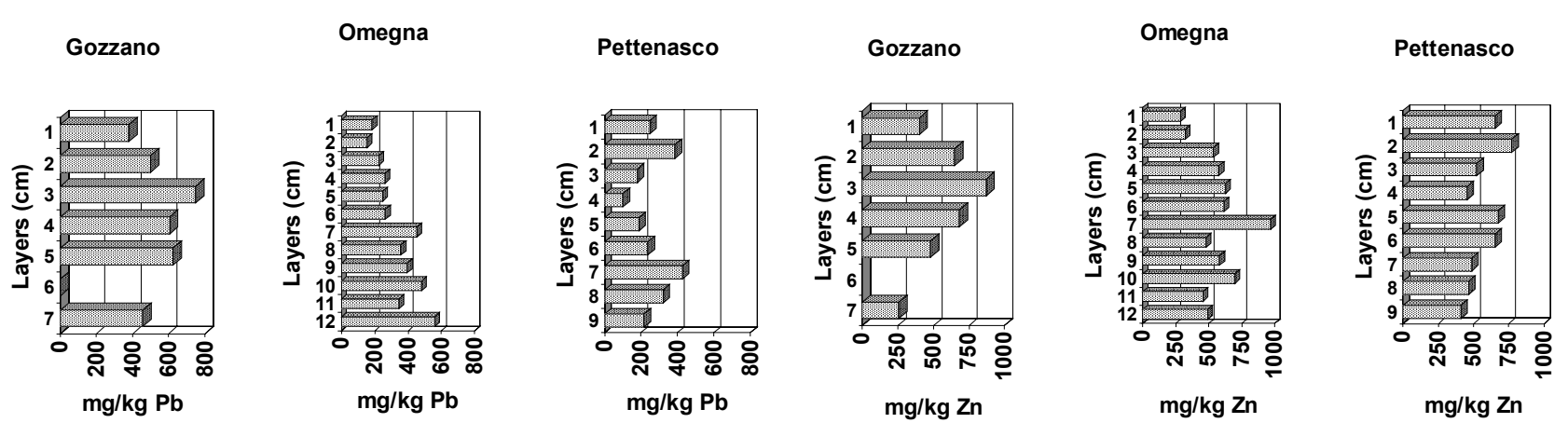

Fig. 9. $\mathrm{Pb}$ profiles $\left(\mathrm{mg} \mathrm{kg}^{-1}\right)$. For each core, the deepest layers date back to 1954 (from the data of Provini et al. 1987).

In another study (Provini et al. 1987) three cores from Gozzano, Pettenasco and Omegna were collected and sectioned in $1 \mathrm{~cm}$ layers. In this case, organic carbon was measured by means of a CHN Elemental Analyser, nitrogen with the Scheiner (1976) method, total phosphorus by spectrometry (phosphomolibdic complex) after ashing at $450{ }^{\circ} \mathrm{C}$ and extraction with $1 \mathrm{~N}$ sulphuric acid for 3 hours, organic matter by ashing at 450 ${ }^{\circ} \mathrm{C}$ for 24 hours, and chlorophyll derivatives and total carotenoids by acetone extraction (Vallentyne 1956; Fogg \& Belcher 1961). The metals $\mathrm{Cd}, \mathrm{Cr}, \mathrm{Cu}, \mathrm{Pb}$ and $\mathrm{Zn}$ were measured by flame atomic absorption spectrometry following wet digestion with a 1:1 mixture of
Fig. 10. $\mathrm{Zn}$ profiles $\left(\mathrm{mg} \mathrm{kg}^{-1}\right)$. For each core, the deepest layers date back to 1954 (from the data of Provini et al. 1987).

nitric and perchloric acids (Julshamm \& Braekkan 1975), Hg was quantified by volatile hydride AAS (Gaggino 1980), and the sedimentation rate with the ${ }^{137} \mathrm{Cs}$ technique (Robbins \& Edgington 1975, Premazzi 1979, Premazzi \& Parise 1986). Results of this study indicated that phosphorus in sediments diminished by $50 \%$ since 1954, although organic matter remained almost constant in the three basins studied. Metals also tended to decrease (Figs 5-10), but concentrations remained high enough to represent a potential hazard for the environment.

In 1985 (Baudo et al. 1989) 52 sediment samples were collected by means of a Ponar grab, to sample 

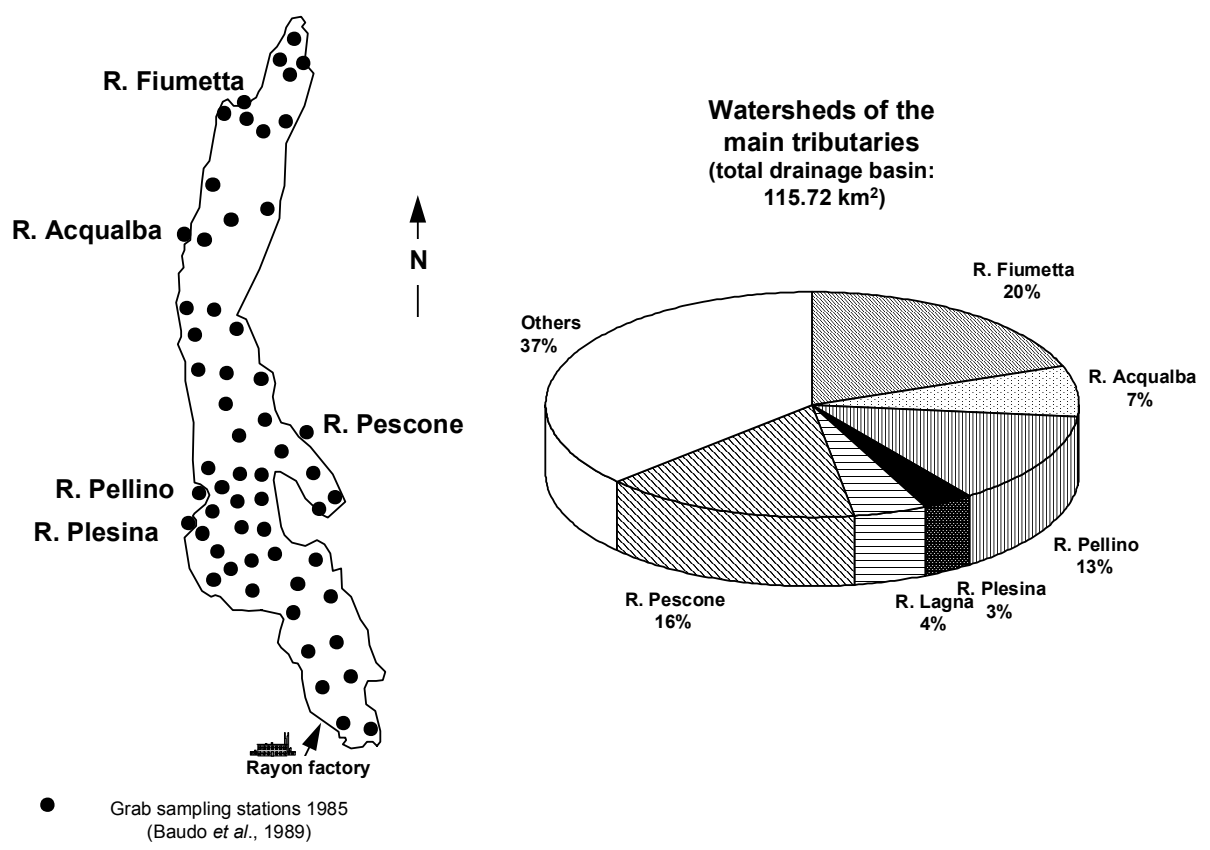

Watersheds of the

main tributaries

drainage basin:

Fig. 11. Sampling stations in 1985 (Baudo et al. 1989).

about $500 \mathrm{~cm}^{2}$ of the top layer $(10-15 \mathrm{~cm})$. The sampling stations were irregularly distributed, according to the morphometric characteristics of the lake (Fig. 11), and 5 additional sediment samples were collected from the mouths of tributaries (Plesina, Pellino, Acqualba, Fiumetta, Pescone) in order to investigate the composition of the particulate matter which is transported into Lake Orta.

At the Environment Institute, Joint Research Centre of Ispra, all samples were air dried, sieved $(>200 \mu \mathrm{m})$ and ground in a zircon oxide planetary mill till a grain size $<90 \mu \mathrm{m}$ was obtained. The analyses thus refer to the whole sediment, as recommended e.g. by Jones \& Bowser (1978), and not to specific size classes or chemical "species" identified by differential elution.

Total carbon $\left(\mathrm{C}_{\text {tot }}\right)$ and its organic fraction $\left(\mathrm{C}_{\mathrm{org}}\right)$ were determined by combustion in an oxygen stream at 1200 and $600{ }^{\circ} \mathrm{C}$, respectively, followed by measurement by differential conductivity (Kock \& Malissa 1957). Sample aliquots were combusted at $1200{ }^{\circ} \mathrm{C}$ for measurement of total organic sulphur and sulphides. Organic and ammonia nitrogen were determined by titration following Kjeldahl digestion.

Inorganic phosphorus $\left(\mathrm{P}_{\text {inorg }}\right)$ and total phosphorus $\left(\mathrm{P}_{\text {tot }}\right)$ were colorimetrically measured (Vogler 1965) after extraction in $1 \mathrm{~N}$ sulphuric acid, or digestion with sulphuric acid, nitric acid, and hydrogen peroxide (Marengo \& Baudo 1988). The difference between these two fractions provided an estimation of the organic phosphorus $\left(\mathrm{P}_{\text {org }}\right)$.
Macro- and microelements ( $\mathrm{Si}, \mathrm{Ca}, \mathrm{Mg}, \mathrm{K}, \mathrm{Al}, \mathrm{Fe}$, $\mathrm{Ti}, \mathrm{Mn}, \mathrm{Pb}, \mathrm{Cu}, \mathrm{Cr}, \mathrm{Ni}, \mathrm{Zn}$ ) were determined by $\mathrm{X}$ Ray fluorescence spectrometry, while B, V, Sr, Sn, Mo, Co, $\mathrm{Be}, \mathrm{Li}, \mathrm{Cd}$, and $\mathrm{Hg}$ were measured by inductively coupled plasma emission after pressure digestion in Teflon vessels with $0.5 \mathrm{ml} \mathrm{HF}$ and $1.5 \mathrm{ml} \mathrm{HNO}_{3}$ at $170{ }^{\circ} \mathrm{C}$ for 24 hours. Sampling data was collected at a level of greater than 3 samples $\mathrm{km}^{-2}$, and this information was synthesised into distribution maps for the different elements using the kriging technique (Baudo 1989, 1990). Baudo et al. (1989) concluded that industrial pollution observed in the 1985 samples still marked the sediments as heavily contaminated, but observed trends appeared to indicate that conditions were improving and the lake was likely to recover.

In 1986 pooled samples were created by combining corresponding sections (1 cm layers) of three cores collected with a Jenkin corer in the central basin at a depth of $120 \mathrm{~m}$. These samples were extracted with a 1:1 mixture of $90 \%$ acetone and ethanol for spectrophotometric determination and chromatographic detection of chlorophyll derivatives and carotenoids. Copper was measured in these sediment samples by flame AAS, after pressure digestion with $\mathrm{HF}$ and $\mathrm{HNO}_{3}$ (Guilizzoni \& Lami 1988).

This research demonstrated that the installation of a copper recovery plant at the rayon factory in 1958 resulted in a sharp decrease in sediment metal concentrations, although deposition increased again in the 1960s (Fig. 12). Pigment degradation products increased shortly thereafter, probably because the physico-chemi- 


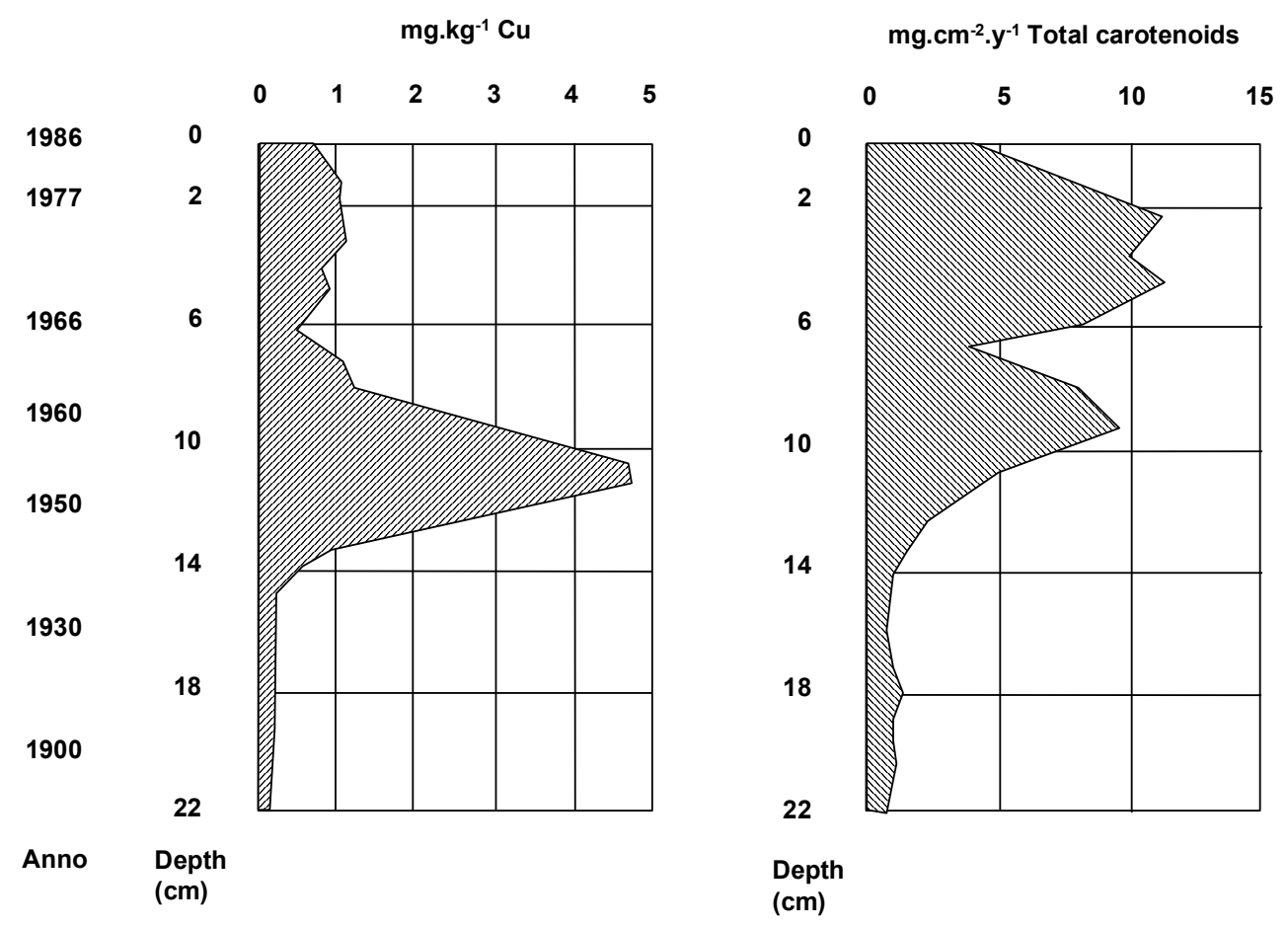

Fig. 12. Distribution profiles for $\mathrm{Cu}\left(\mathrm{mg} \mathrm{kg}^{-1}\right)$ and total carotenoids $\left(\mathrm{mg} \mathrm{cm}^{-2} \mathrm{y}^{-1}\right)$ in a core collected in 1986 (after Guilizzoni \& Lami 1988).

cal conditions of the sediments resulted in better conservation of the pigments. Guilizzoni \& Lami (1988) concluded that the sedimentation rates changed over time, from $2 \mathrm{~mm} \mathrm{y}^{-1}$ (from 22 to $16 \mathrm{~cm}$ ), to $1.5 \mathrm{~mm} \mathrm{y}^{-1}$ $(16-9 \mathrm{~cm})$, and $3.4 \mathrm{~mm} \mathrm{y}^{-1}$ (top layer), as a result of the changes in the trophic status of the lake.

In 1986 (Trevisan 1992), a core of $490 \mathrm{~cm}$ was collected by a percussion corer in a station located outside the range of influence of the rayon factory effluents. This core was sectioned into $1 \mathrm{~cm}$ layers through a depth of $50 \mathrm{~cm}$, then into $2 \mathrm{~cm}$ layers to the bottom. All samples were dried at $40{ }^{\circ} \mathrm{C}$, ground in an agate mortar, then analysed for $\mathrm{C}$ and $\mathrm{N}$ (CHN Elemental Analyser), $\mathrm{Al}, \mathrm{Ca}, \mathrm{Fe}, \mathrm{K}, \mathrm{Mg}, \mathrm{P}, \mathrm{Si}, \mathrm{S}, \mathrm{Cr}, \mathrm{Ni}, \mathrm{Pb}, \mathrm{Cu}, \mathrm{Zn}, \mathrm{Mn}$ (XRay fluorescence spectrometry), and U, Se, Yb, Th, Ti, Cr, Hf, Nd, As, Cs, La, Sc, Rb, Eu, Fe, Co, Ta, V, Sb, $\mathrm{Mn}$ (nuclear activation analysis). Due to its location, this station was less influenced by the industrial pollution than those sampled in the previous research. More precisely, the distribution profiles of the different elements showed a trend of increasing concentrations for $\mathrm{Pb}$, As, $\mathrm{La}$, Th, and Ta. $\mathrm{Cu}, \mathrm{K}$, and Co displayed mild variation, while $\mathrm{Zn}, \mathrm{Sb}, \mathrm{Fe}, \mathrm{Sc}, \mathrm{Rb}, \mathrm{Ca}, \mathrm{Mg}, \mathrm{Si}, \mathrm{Ti}, \mathrm{Mn}$, $\mathrm{S}, \mathrm{P}, \mathrm{C}, \mathrm{Cr}, \mathrm{Ni}, \mathrm{V}, \mathrm{Eu}$ and $\mathrm{Cs}$ were decreasing from the deeper to the shallower sections of the core.

However, the most recent strata of sediments still have concentrations of $\mathrm{As}, \mathrm{Ni}, \mathrm{Cu}, \mathrm{Cr}, \mathrm{Pb}, \mathrm{Zn}, \mathrm{P}, \mathrm{N}$, and $\mathrm{P}$ high enough to classify the lake as "heavily polluted", according to the criteria proposed by the US Environment Protection Agency (Giesy \& Hoke 1990).

\section{POST-LIMING STUDIES}

In 1992 (Baudo et al. 1993), 7 sediment samples were collected by Ponar grab and, in three representative points, by means of a gravity corer. To compare recent sediments with those of a pre-industrial time, the three cores were divided in a surficial layer $(0-10 \mathrm{~cm})$, a mid-layer, and the last $10 \mathrm{~cm}$ (Fig. 13). Both grab samples and core sections were carefully homogenised and sub-sampled for chemical analyses (Baudo et al. 1993) of pore water (centrifugation at $4500 \mathrm{rpm}$ for $45 \mathrm{~min}$ at $4{ }^{\circ} \mathrm{C}$ ), and for toxicity testing (Baudo 1994; Baudo et al. 1996).

Since the sediment analyses were done in the same way as the 1985 sampling (Baudo et al. 1989), the results of the two studies can be compared to assess the effects on sediments of the liming of the lake waters (Baudo et al. 1993), which drastically reduced the water column dissolved metal concentrations (Camusso et al. 1989a, b; Camusso \& Tartari 1991; Camusso et al. $1991 b, c)$.

In 1996 sediment samples were taken again at the same stations as in 1985 and 1992 studies. In this case, only the first $2 \mathrm{~cm}$ of the Ponar grab samples were collected, accounting only for the sediment deposited after the liming period. All samples were air dried and homogenized by sieving ( $200 \mu \mathrm{m}$ pore size), then macroand microelements ( $\mathrm{Si}, \mathrm{Al}, \mathrm{Fe}, \mathrm{Ti}, \mathrm{Ca}, \mathrm{K}, \mathrm{Mg}, \mathrm{Na}, \mathrm{P}, \mathrm{S}$, $\mathrm{Pb}, \mathrm{Zn}, \mathrm{Cu}, \mathrm{Ni}, \mathrm{Mn}, \mathrm{Cr}$ ) were determined by X-Ray 

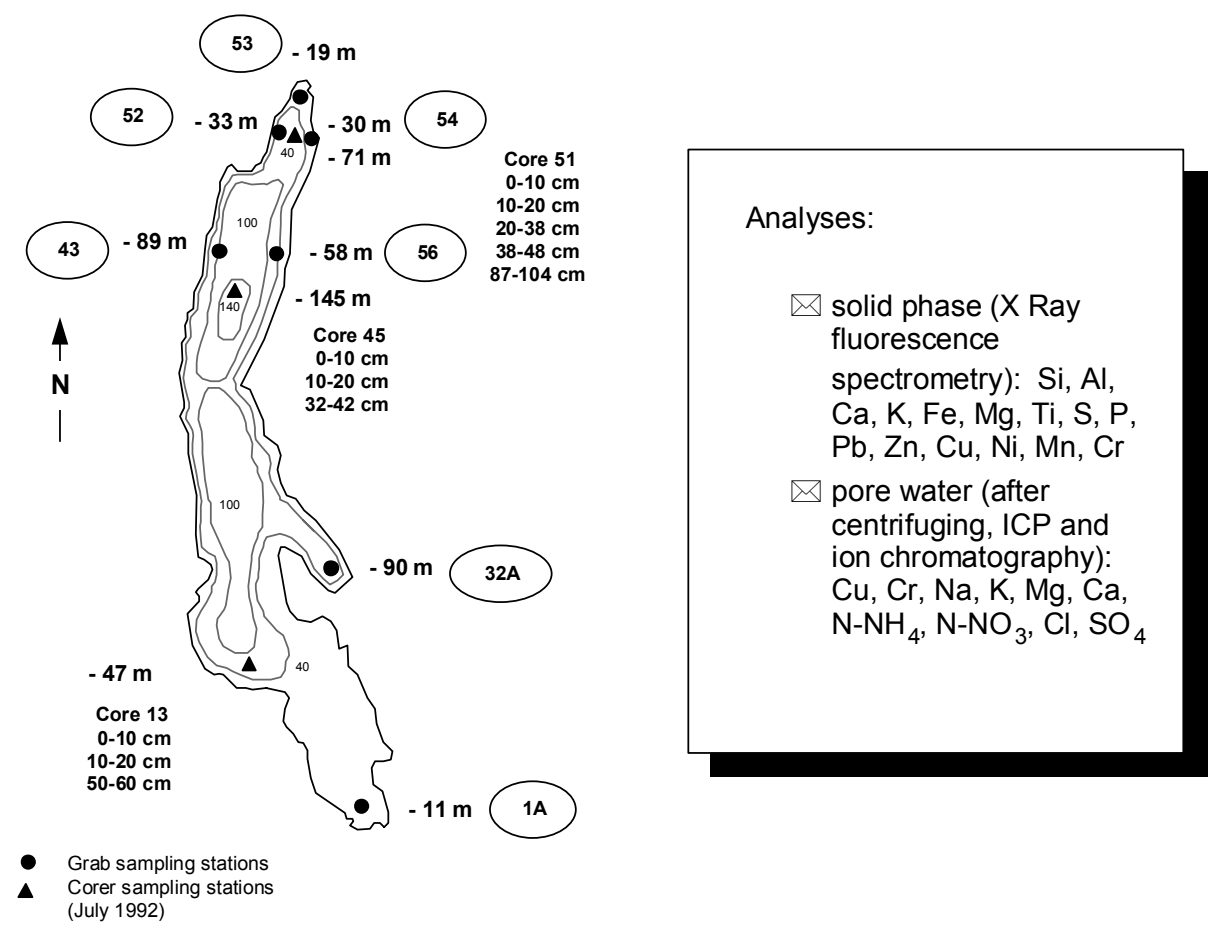

Fig. 13. 1992 sampling and analyses.

fluorescence spectrometry, and $\mathrm{C}$ and $\mathrm{N}$ by means of a CHN Elemental Analyzer.

\section{PRE- AND POST-LIMING COMPARISON}

The data on sediments are subdivided into 5 groups (Kemp et al. 1976): nutrient elements (Organic C, N, P); carbonate elements (carbonate $\mathrm{C}, \mathrm{Ca}$, and $\mathrm{Mg}$ ); conservative elements ( $\mathrm{Si}, \mathrm{Al}, \mathrm{K}, \mathrm{Mg}, \mathrm{Ti}, \mathrm{Na})$; enriched elements $(\mathrm{Cd}, \mathrm{Pb}, \mathrm{Cu}, \mathrm{Cr}, \mathrm{Ni}, \mathrm{Hg}, \mathrm{Zn})$; and mobile elements (Fe, Mn, S).

\subsection{Nutrient elements}

For nutrients (Tab. 1), the sediments obviously reflect the input from urban discharges of the 30,000 inhabitants of the drainage basin (Lacqua et al. 1983); these inputs flowed untreated into the lake until 1987, when a sewage treatment plant came on line at Omegna. Most effluents are currently collected and treated, and they do not flow into the lake but are directly discharged into the outlet, River Niguglia (Bonacina et al. 1986).

Determination of the organic and inorganic carbon fractions was only possible for the 1985 samples due to resource limitations. The distribution maps of total carbon and organic carbon (Fig. 14) show that the carbonate input from the watershed is quite low, and in fact the organic fraction of this element accounts for $92 \%$ of the total carbon.

In 1996 (Fig. 15) the total carbon mean concentration is doubled, while $\mathrm{Ca}$ (see discussion below) is in- creased by only $35 \%$. These differences are most likely due to the sedimentation of organic matter.

Nitrogen increased by $120 \%$ from 1985 to 1996 (Fig. 16). In sediment, nitrogen is present almost entirely in an organic form, and its map of distribution overlaps with that of carbon and is also complementary to that of silicium, which represents the main mineral input to the sediments. Moreover, the data on pore water show high concentrations of another potential toxicant, ammonia nitrogen, which could interfere with benthic organisms (Baudo 1994).

The $\mathrm{C} / \mathrm{N}$ ratio of lacustrine sediments can be used to assess the autochthonous or allochthonous source of the organic matter (Håkanson \& Jansson 1983); this ratio has a value of 6 for phytoplankton, between 5 and 6 for zooplankton, but increases to 25-40 for terrestrial or riparian higher plants. Conventionally, the value of 10 is assumed as an index to distinguish between autochthonous and allochthonous material. In L. Orta the mean $\mathrm{C} / \mathrm{N}$ ratio was 11.7 in 1985 and 10.7 in 1996; therefore the recently sedimented organic matter reflects an higher proportion of planktonic material. This finding confirms the conclusions of Guilizzoni \& Lami (1990), who found that $80 \%$ of the material in a core collected from the deepest point of the lake in 1986 produced $\mathrm{C} / \mathrm{N}$ ratios ranging from 8 to 9 , suggesting that the autochthonous fraction was predominant, and that recovery of the phytoplanktonic populations had begun. For phosphorus, the increase between 1985 and 1996 (Fig. 17) was clearly shown also by the data from the 1992 cores (Tab. 1). 
Tab. 1. Nutrients in Lake Orta sediments and pore water.

Surficial sediment

\begin{tabular}{|c|c|c|c|c|c|c|c|c|c|}
\hline & \multicolumn{3}{|c|}{1985} & \multicolumn{3}{|c|}{1992} & \multicolumn{3}{|c|}{1996} \\
\hline & Mean & $\min$ & Max & Mean & $\min$ & $\operatorname{Max}$ & Mean & $\min$ & Max \\
\hline Total C \% & 3.87 & 0.05 & 9.26 & & & & 7.72 & 0.19 & 15.52 \\
\hline Organic C \% & 3.55 & 0.04 & 8.89 & & & & & & \\
\hline $\mathrm{N} \%$ & 0.33 & 0.01 & 0.88 & & & & 0.73 & 0.12 & 1.32 \\
\hline $\mathrm{P} \%$ & 0.13 & 0.05 & 0.24 & 0.19 & 0.09 & 0.26 & 0.20 & 0.07 & 0.29 \\
\hline
\end{tabular}

$\underline{\text { Sediment cores }}$

\begin{tabular}{ccc}
\hline Core & Section & $\% \mathrm{P}$ \\
\hline 51 & $0-10$ & 0.26 \\
& $10-20$ & 0.17 \\
& $20-38$ & 0.14 \\
& $38-48$ & 0.14 \\
45 & $87-104$ & 0.11 \\
& $0-10$ & 0.16 \\
& $10-20$ & 0.15 \\
13 & $32-42$ & 0.14 \\
& $0-10$ & 0.20 \\
& $10-20$ & 0.13 \\
& $50-60$ & 0.11 \\
\hline
\end{tabular}

$\underline{\text { Pore water }\left(\mathrm{mg} \mathrm{l}^{-1}\right)}$

\begin{tabular}{ccccc}
\hline Sample & Type & Section & $\mathrm{N}^{2} \mathrm{NH}_{4}$ & $\mathrm{~N}-\mathrm{NO}_{3}$ \\
\hline 56 & Grab & & 3.24 & 0.00 \\
54 & Grab & & 3.91 & 0.02 \\
53 & Grab & & 4.84 & 0.03 \\
52 & Grab & & 3.35 & 0.07 \\
43 & Grab & & 8.69 & 0.01 \\
32 & Grab & & 7.42 & 0.01 \\
1 & Grab & $0-10$ & 5.05 & 0.04 \\
51 & Core & $10-20$ & 6.14 & 0.08 \\
& & $38-48$ & 7.97 & 0.08 \\
& & $0-10$ & 9.86 & 0.02 \\
45 & Core & $10-20$ & 10.26 & 0.01 \\
& & $32-42$ & 10.70 & 0.02 \\
& & $0-10$ & 2.44 & 0.03 \\
13 & Core & $10-20$ & 3.78 & 0.03 \\
& & $50-60$ & 2.47 & 0.03 \\
\hline
\end{tabular}

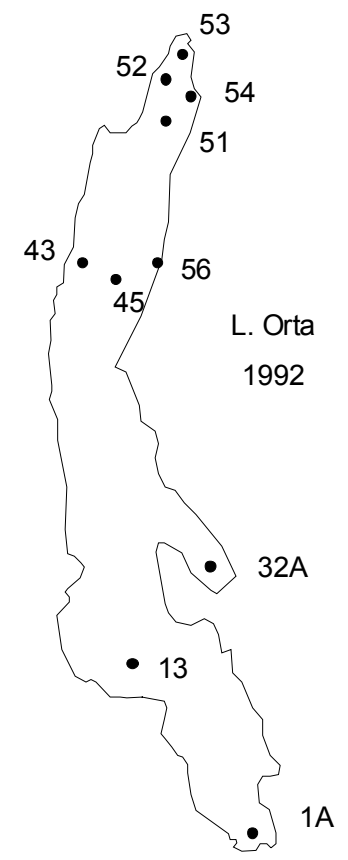



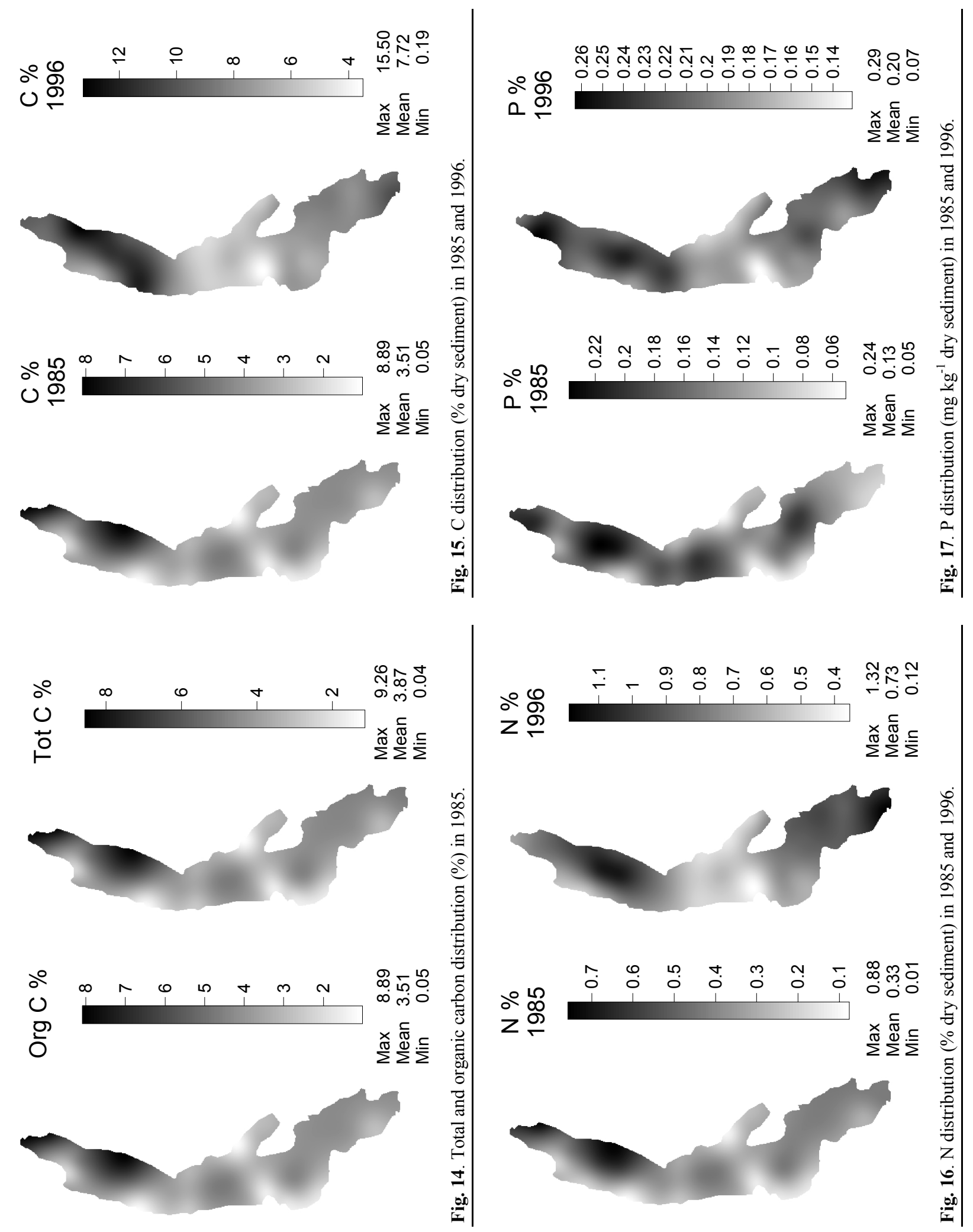


\subsection{Carbonate elements}

The fraction of carbon bound to carbonates was not been determined for the 1992 and 1996 samples, therefore the possible increase due to the liming can be inferred only from the data for total carbon (as previously discussed). Calcium and magnesium, however, were measured both in 1992 and 1996 (Tab. 2). The distribution maps for these two elements (Figs 18-19) in 1985 confirmed that these elements were relatively scarce in the drainage basin, and measured concentrations compare well with the mainly siliceous rock composition of the watershed.

However, in 1996 the sediments showed a noticeable increase in $\mathrm{Ca}$, which is clearly related to the liming of the lake. Such an increase was not shown by $\mathrm{Mg}$, since the raw product used for the treatment was composed of $92 \% \mathrm{CaCO}_{3}, 6 \% \mathrm{MgCO}_{3}$ and $2 \%$ of siliceous impurities (Calderoni \& de Bernardi 1992). Hence, in this case magnesium, which is present not only in limestone, but also in silicates, behaves more like the other conservative elements.

In pore water (Tab. 2), the concentrations of these metals were comparable to those measured into the water column, ranging from 6.3 to $9.1 \mathrm{mg} \mathrm{l}^{-1}$ for $\mathrm{Ca}$, around $1.5 \mathrm{mg} \mathrm{l}^{-1}$ for $\mathrm{Mg}$ (Calderoni \& Mosello 1990).

\subsection{Conservative elements}

Conservative elements, by definition, "make up the bulk of the sediment matrix and are unlikely to be affected by diagenesis or increasing eutrophication to the lake". In fact, they reflect "the major mineralogical species derived from terrigenous sources" (Kemp et al. 1976).

Tab. 2. Carbonate elements in Lake Orta sediments and pore water (1992 sampling).

Surficial sediment

\begin{tabular}{|c|c|c|c|c|c|c|c|c|c|}
\hline & \multicolumn{3}{|c|}{1985} & \multicolumn{3}{|c|}{1992} & \multicolumn{3}{|c|}{1996} \\
\hline & Mean & $\min$ & Max & Mean & $\min$ & Max & Mean & $\min$ & Max \\
\hline $\mathrm{Mg} \%$ & 1.01 & 0.65 & 2.42 & 1.23 & 1.03 & 1.90 & 0.99 & 0.63 & 1.99 \\
\hline $\mathrm{Ca} \%$ & 0.61 & 0.18 & 1.40 & 0.79 & 0.46 & 1.21 & 0.82 & 0.43 & 1.61 \\
\hline
\end{tabular}

\begin{tabular}{lccc}
\multicolumn{4}{l}{ Sediment cores } \\
Station & Section & $\% \mathrm{Ca}$ & $\% \mathrm{Mg}$ \\
\hline 51 & $0-10$ & 0.71 & 1.21 \\
& $10-20$ & 0.54 & 1.18 \\
& $20-38$ & 0.89 & 1.30 \\
& $38-48$ & 0.68 & 1.18 \\
45 & $87-104$ & 0.68 & 1.18 \\
& $0-10$ & 0.96 & 1.36 \\
& $10-20$ & 0.75 & 1.27 \\
13 & $32-42$ & 0.96 & 1.51 \\
& $0-10$ & 0.61 & 1.12 \\
& $10-20$ & 0.50 & 1.06 \\
& $50-60$ & 0.54 & 1.06
\end{tabular}

Pore water $\left(\mathrm{mg} \mathrm{l}^{-1}\right)$

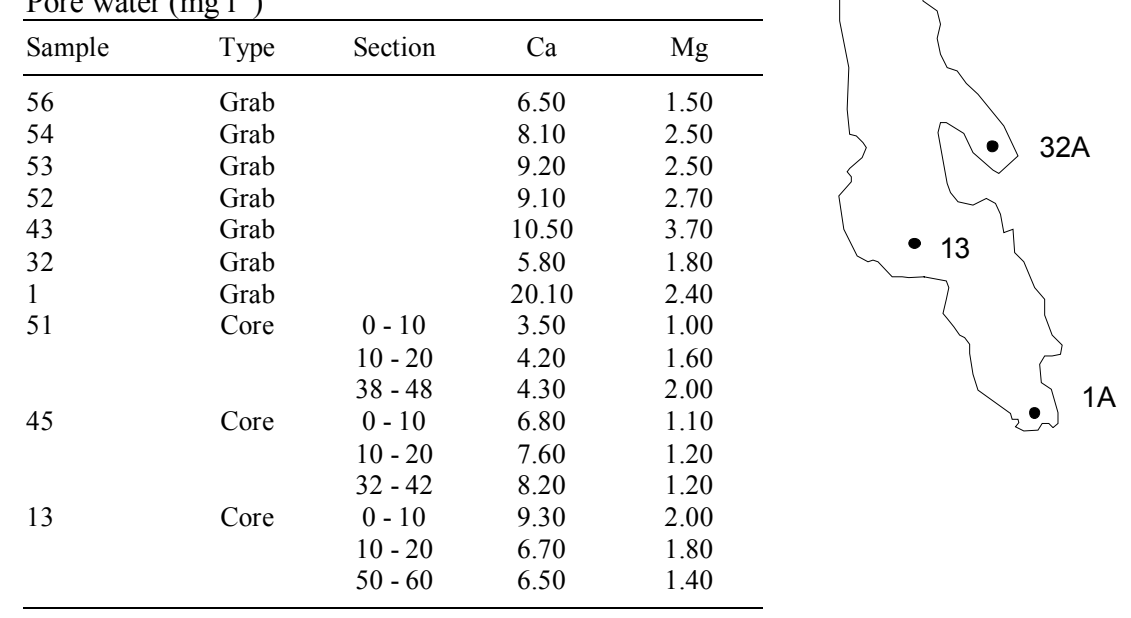



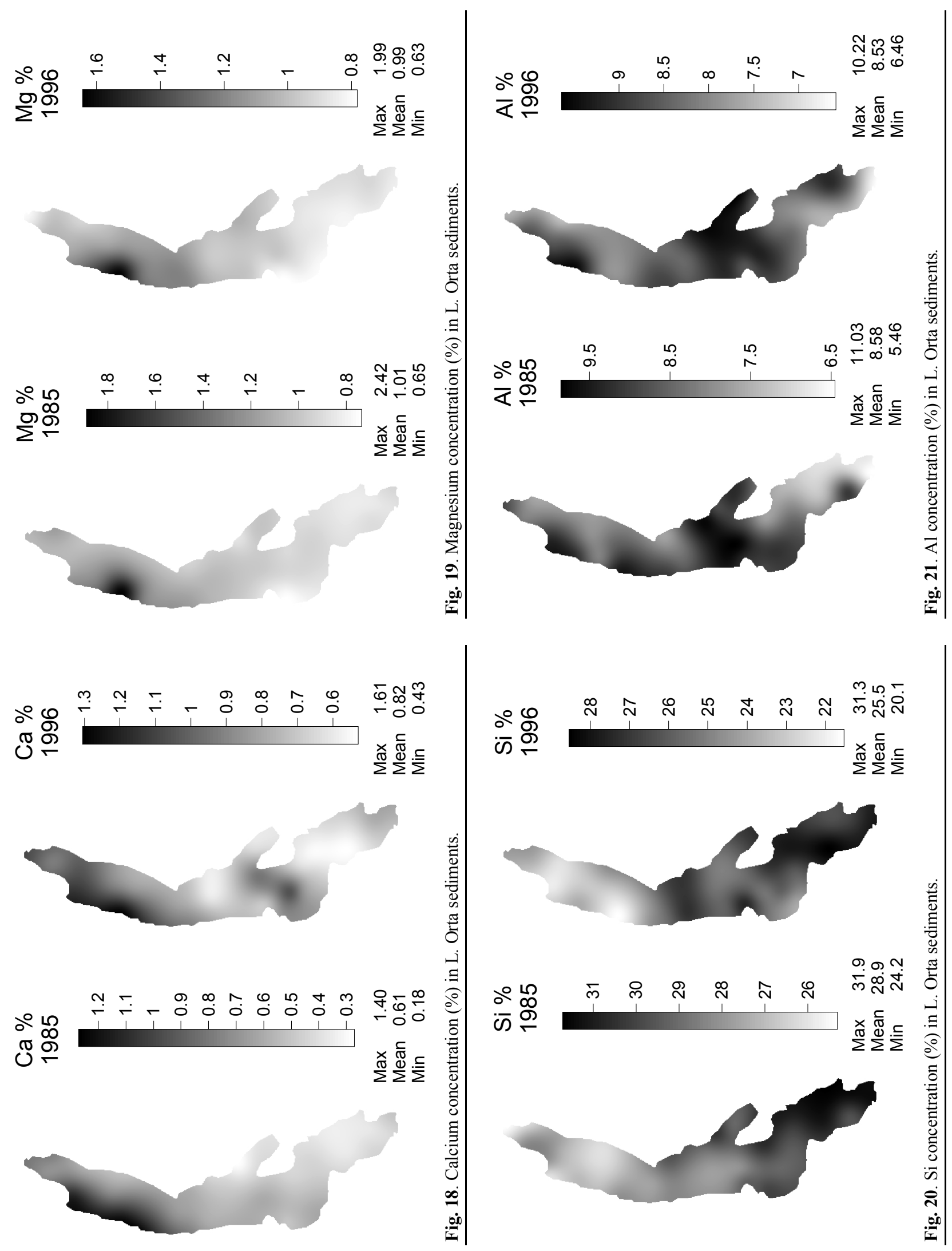
The concentrations of these elements in sediments depend mainly on the geochemistry of the watershed, and the differences among stations reflect the sedimentation pattern produced by hydraulic factors, as well as variability in the geochemistry of those portions of the watershed drained by the lake tributaries. Since these elements are present in the sediments in high concentrations (in fact, expressed by $\%$ dry weight), variations over time are usually quite low (Tab. 3).

For $\mathrm{Si}$, the input is mainly controlled by the geochemical characteristics of the different part of the watershed. Hence, considering the homogeneity of the drainage basin, the composition of the detritus flowing into the lake should be relatively constant. However, the variable amount of the organic matter produces a sort of solid-solid "dilution" of the sediments and, as a result, also the Si distribution map shows a variability, with a decrease from South to North (Fig. 20). For pore water, only data for sodium and potassium are available. Concentrations in interstitial waters show spatial variability, but they are close to those measured in the water column (around $5.0 \mathrm{mg} \mathrm{Na}^{-1}$ and $1.0 \mathrm{mg} \mathrm{K}^{-1}$; Calderoni \& Mosello 1990).

Tab. 3. Conservative elements in Lake Orta sediments.

$\underline{\text { Surficial sediment }}$

\begin{tabular}{|c|c|c|c|c|c|c|c|c|c|}
\hline & \multicolumn{3}{|c|}{1985} & \multicolumn{3}{|c|}{1992} & \multicolumn{3}{|c|}{1996} \\
\hline & Mean & $\min$ & Max & Mean & $\min$ & Max & Mean & Min & Max \\
\hline Si \% & 28.9 & 24.2 & 31.9 & 26.9 & 24.2 & 31.3 & 25.5 & 20.1 & 31.3 \\
\hline $\mathrm{Al} \%$ & 8.58 & 5.46 & 11.03 & 8.53 & 6.46 & 10.06 & 8.53 & 6.46 & 10.22 \\
\hline Ti \% & 0.39 & 0.02 & 0.61 & 0.45 & 0.38 & 0.58 & 0.44 & 0.27 & 0.61 \\
\hline K \% & 2.17 & 1.02 & 4.28 & 1.90 & 1.54 & 2.32 & 2.00 & 1.41 & 3.11 \\
\hline $\mathrm{Na} \%$ & & & & & & & 1.05 & 0.67 & 2.23 \\
\hline
\end{tabular}

Sediment cores

\begin{tabular}{lccccc}
\hline Station & Section & $\mathrm{Si}$ & $\mathrm{Al}$ & $\mathrm{Ti}$ & $\mathrm{K}$ \\
\hline 51 & $0-10$ & 25.39 & 8.28 & 0.46 & 1.66 \\
& $10-20$ & 28.24 & 8.02 & 0.43 & 1.49 \\
& $20-38$ & 26.65 & 9.92 & 0.54 & 2.16 \\
& $38-48$ & 27.77 & 9.37 & 0.48 & 1.91 \\
45 & $87-104$ & 28.26 & 9.66 & 0.36 & 2.53 \\
& $0-10$ & 25.69 & 10.06 & 0.58 & 2.20 \\
& $10-20$ & 26.55 & 9.34 & 0.51 & 1.87 \\
13 & $32-42$ & 25.50 & 10.48 & 0.57 & 2.24 \\
& $0-10$ & 28.10 & 8.57 & 0.40 & 1.74 \\
& $10-20$ & 29.43 & 8.87 & 0.40 & 1.66 \\
& $50-60$ & 30.08 & 8.02 & 0.40 & 1.66 \\
\hline
\end{tabular}

Pore water $\left(\mathrm{mg} \mathrm{l}^{-1}\right)$

\begin{tabular}{lcccc}
\hline Sample & Type & Section & $\mathrm{Na}$ & $\mathrm{K}$ \\
\hline 56 & Grab & & 5.10 & 1.30 \\
54 & $\mathrm{Grab}$ & & 5.10 & 1.30 \\
53 & $\mathrm{Grab}$ & & 5.20 & 1.30 \\
52 & $\mathrm{Grab}$ & & 5.00 & 1.10 \\
43 & $\mathrm{Grab}$ & & 5.40 & 2.10 \\
32 & Grab & & 5.30 & 2.20 \\
1 & Grab & & 6.10 & 1.30 \\
51 & Core & $0-10$ & 5.20 & 1.80 \\
& & $10-20$ & 4.40 & 1.30 \\
& & $38-48$ & 3.80 & 1.60 \\
45 & Core & $0-10$ & 4.70 & 2.00 \\
& & $10-20$ & 4.40 & 2.00 \\
& & $32-42$ & 3.70 & 2.00 \\
13 & Core & $0-10$ & 6.10 & 1.40 \\
& & $10-20$ & 6.20 & 1.30 \\
& & $50-60$ & 8.40 & 1.40 \\
\hline
\end{tabular}

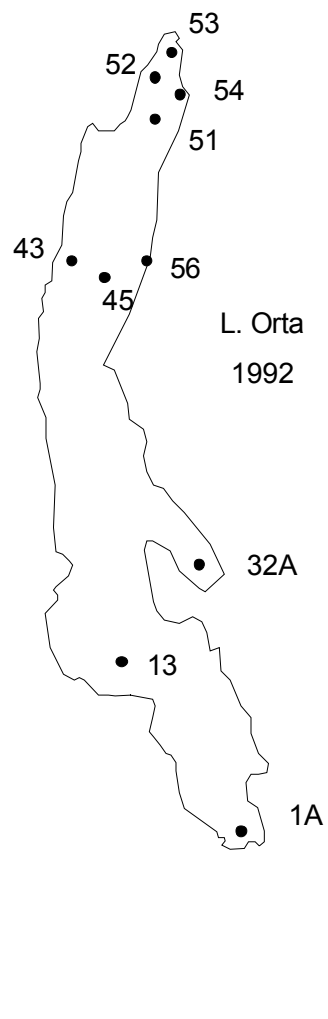




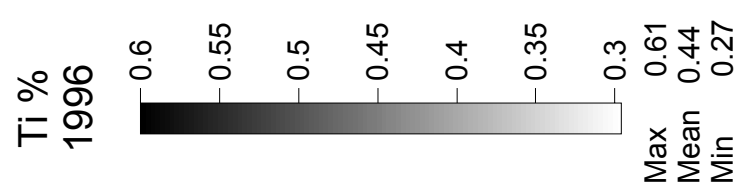
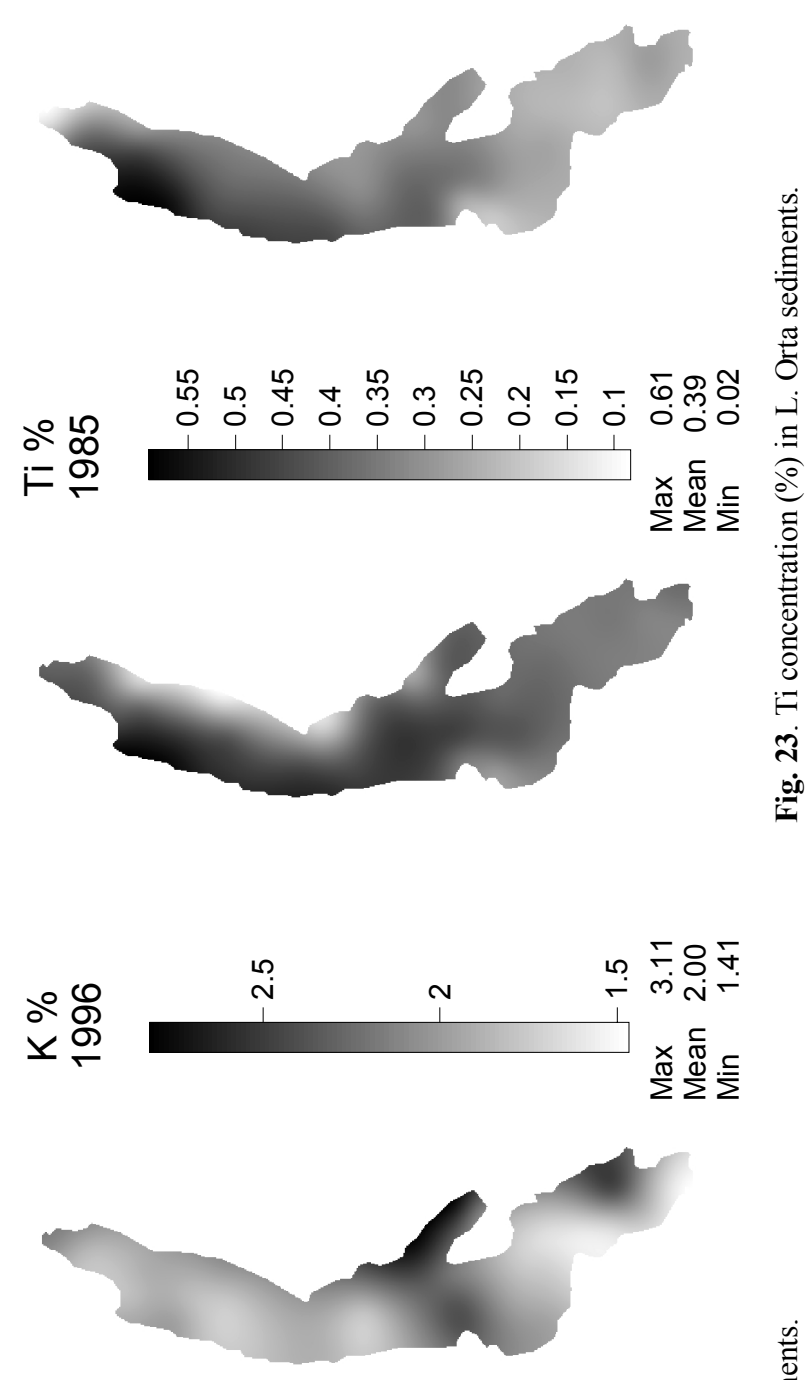

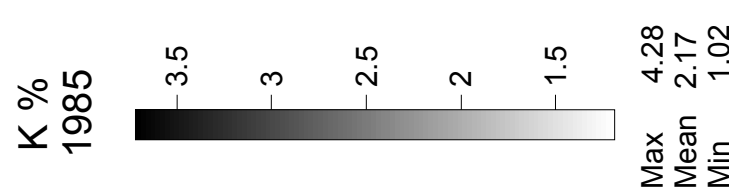

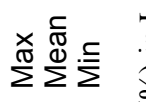

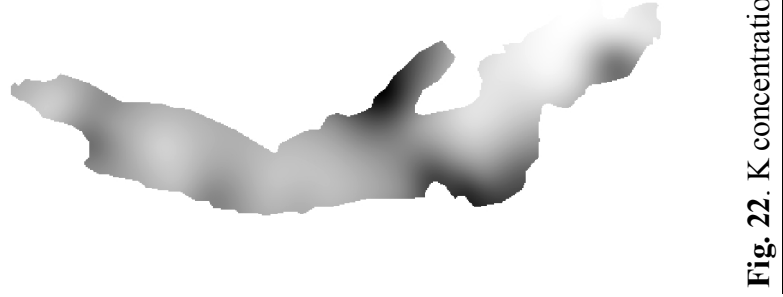

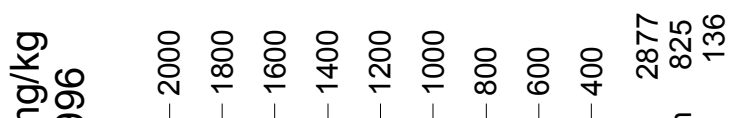
ह่

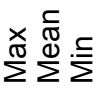

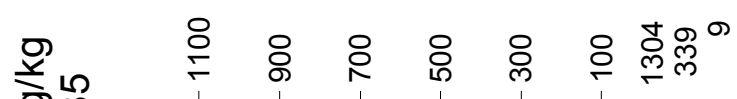

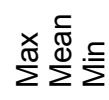
产

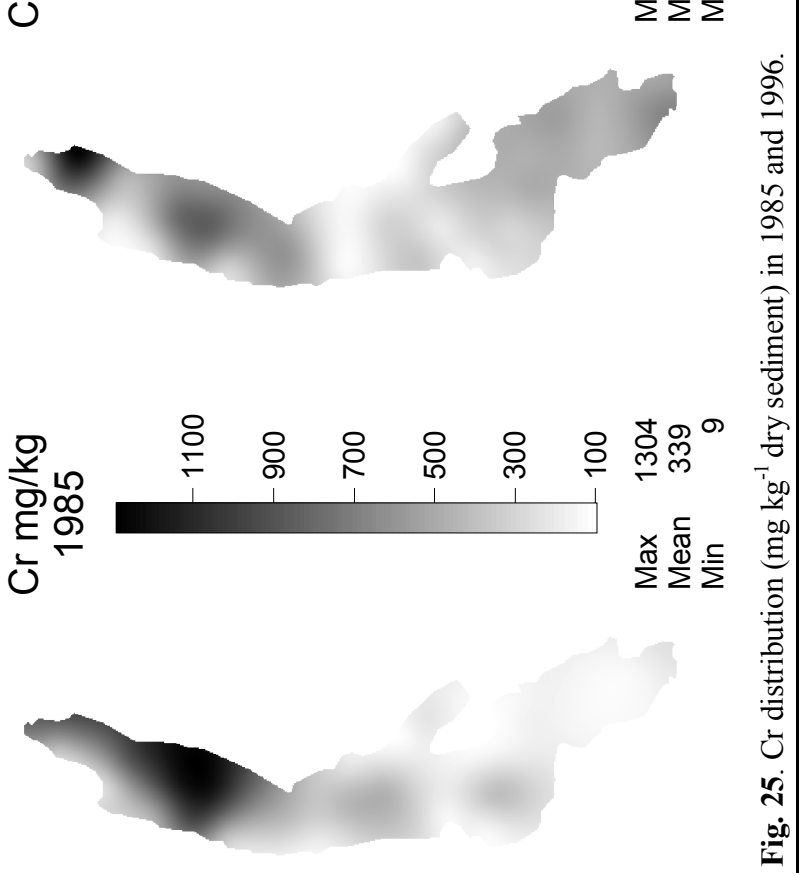

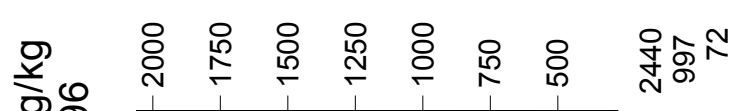

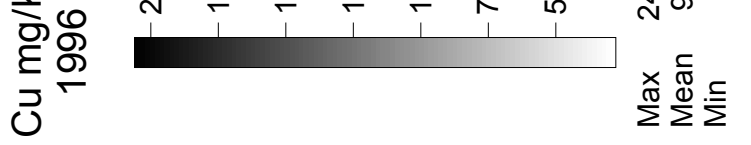

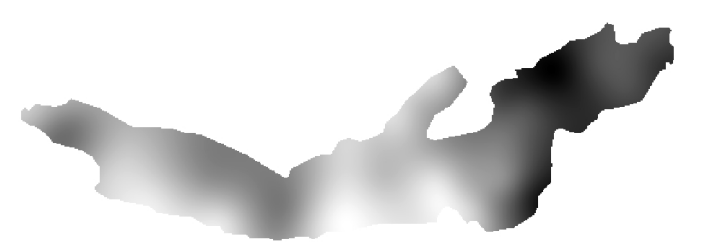

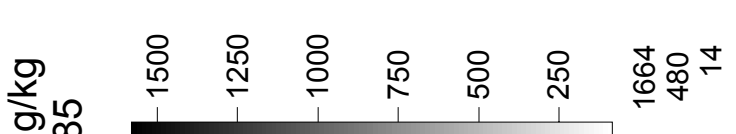

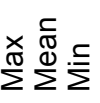
ป 


\subsection{Enriched elements}

By definition, the enriched elements are those extensively used in human activities and therefore their concentrations in sediments are more likely influenced by pollution sources (Tab. 4). For copper, the distribution map for 1985 (Fig. 24) shows an accumulation at the Northern end of the lake. The known pollutant sources are the rayon factory discharge and the River Lagna which delivers effluents of several plating factories into the lake. Both of these lie in the Southern part of the water basin, and results indicate that enriched elements become bound to the particulate matter and then carried from South to North according to the prevailing water flow.

This flow continuously sorts out the particles and, in repeated cycles of sedimentation and resuspension, only the smallest escape the first "sedimentation trap" represented by the central platform, which reaches a depth of $120 \mathrm{~m}$. It is well known that the smallest and lightest particles are often most enriched in trace metals (Salomons et al. 1987). This hypothesis is indirectly confirmed by the similar distribution of the sedimented organic matter, here shown by the maps of carbon, phosphorus, sulphur, and nitrogen; i.e. the components which form the less dense fraction of sediments.

$\mathrm{Cu}$ concentration in sediments were very similar in 1992 and 1985 (Tab. 4); pore water analyses (not performed in 1985) indicate that concentrations in the shallow portions of the cores were much greater than in deeper sections corresponding to pre-industrial times.

Tab. 4. Enriched elements in Lake Orta sediments.

Surficial sediment

\begin{tabular}{|c|c|c|c|c|c|c|c|c|c|}
\hline & \multicolumn{3}{|c|}{1985} & \multicolumn{3}{|c|}{1992} & \multicolumn{3}{|c|}{1996} \\
\hline & Mean & $\min$ & Max & Mean & $\min$ & Max & Mean & $\min$ & Max \\
\hline $\mathrm{Pb}\left(\mathrm{mg} \mathrm{kg}^{-1}\right)$ & 127 & 5 & 542 & 267 & 28 & 569 & 305 & 24 & 660 \\
\hline $\mathrm{Zn}\left(\mathrm{mg} \mathrm{kg}^{-1}\right)$ & 212 & 58 & 807 & 325 & 105 & 701 & 381 & 134 & 1004 \\
\hline $\mathrm{Cu}\left(\mathrm{mg} \mathrm{kg}^{-1}\right)$ & 480 & 14 & 1664 & 843 & 55 & 1978 & 997 & 72 & 2440 \\
\hline $\mathrm{Ni}\left(\mathrm{mg} \mathrm{kg}^{-1}\right)$ & 59 & 16 & 165 & 83 & 54 & 147 & 104 & 30 & 303 \\
\hline $\mathrm{Cr}\left(\mathrm{mg} \mathrm{kg}^{-1}\right)$ & 339 & 9 & 1304 & 1256 & 127 & 6541 & 825 & 136 & 2877 \\
\hline
\end{tabular}

Sediment cores

\begin{tabular}{lcccccc}
\hline Station & Section & $\mathrm{Pb}$ & $\mathrm{Zn}$ & $\mathrm{Cu}$ & $\mathrm{Ni}$ & $\mathrm{Cr}$ \\
\hline 51 & $0-10$ & 407 & 444 & 1351 & 93 & 1856 \\
& $10-20$ & 75 & 122 & 64 & 53 & 156 \\
& $20-38$ & 27 & 102 & 36 & 51 & 101 \\
& $38-48$ & 34 & 104 & 33 & 52 & 92 \\
45 & $87-104$ & 47 & 124 & 28 & 40 & 72 \\
& $0-10$ & 28 & 105 & 55 & 54 & 127 \\
& $10-20$ & 27 & 97 & 31 & 51 & 103 \\
13 & $32-42$ & 24 & 106 & 34 & 60 & 106 \\
& $0-10$ & 239 & 221 & 508 & 71 & 493 \\
& $10-20$ & 54 & 106 & 46 & 49 & 82 \\
& $50-60$ & 29 & 119 & 35 & 50 & 78 \\
\hline
\end{tabular}

Pore water $\left(\mathrm{mg} \mathrm{l}^{-1}\right)$

\begin{tabular}{llccc}
\hline Sample & Type & Section & $\mathrm{Cu}$ & $\mathrm{Cr}$ \\
\hline 56 & Grab & & 0.14 & 0.02 \\
54 & Grab & & 9.04 & 1.26 \\
53 & Grab & & 1.47 & 0.27 \\
52 & Grab & & 0.8 & 0.22 \\
43 & Grab & & 0.25 & 0.26 \\
32 & Grab & & 1.11 & 0.27 \\
1 & Grab & & 0.63 & 0.10 \\
51 & Core & $0-10$ & 1.31 & 0.80 \\
& & $10-20$ & 0.12 & 0.02 \\
& & $38-48$ & 0.12 & 0.02 \\
45 & Core & $0-10$ & 0.17 & 0.03 \\
& & $10-20$ & 0.07 & 0.01 \\
& & $32-42$ & 0.1 & 0.00 \\
13 & Core & $0-10$ & 0.39 & 0.15 \\
& & $10-20$ & 0.13 & 0.02 \\
& & $50-60$ & 0.08 & 0.01
\end{tabular}

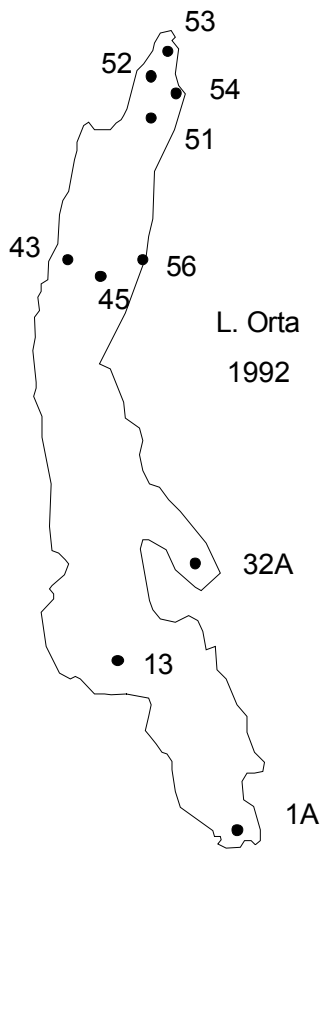




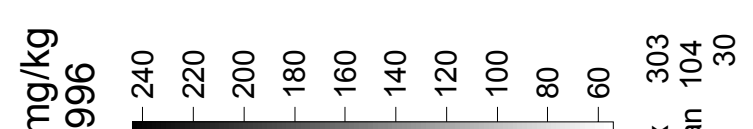

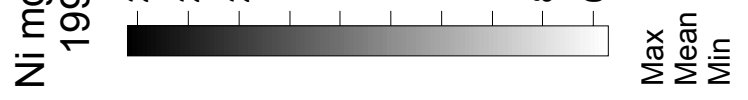

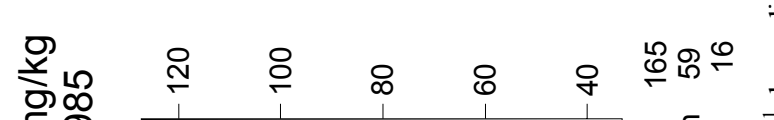

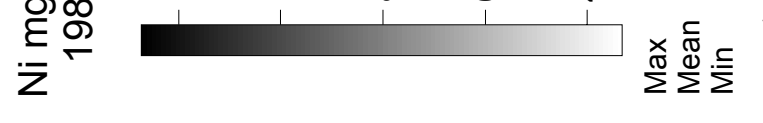

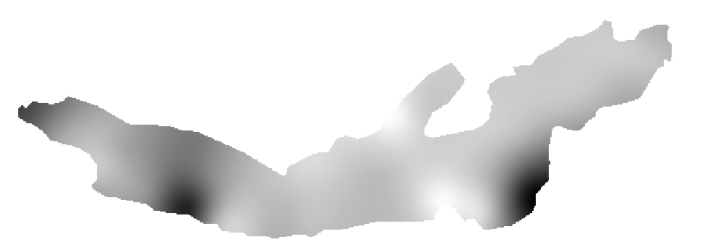

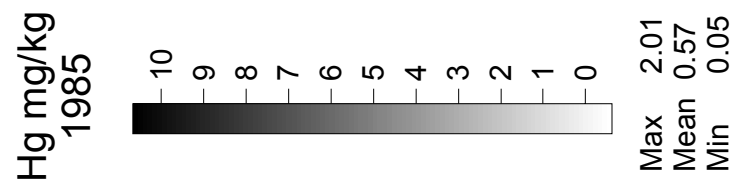

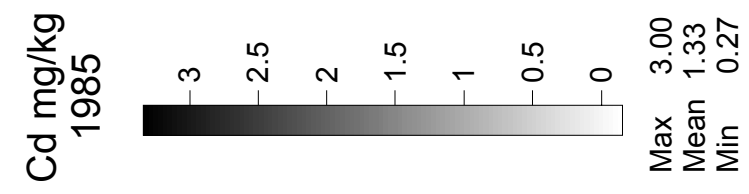

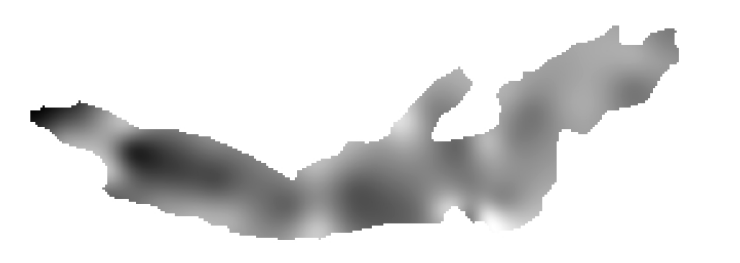

我

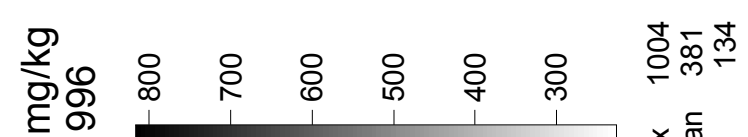
穴

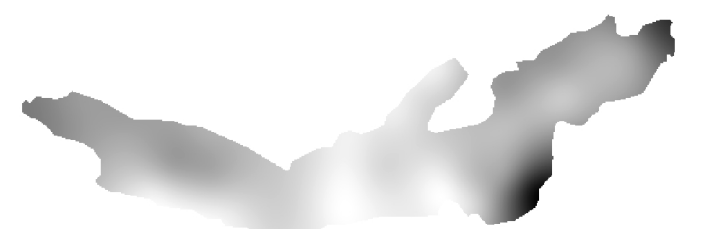

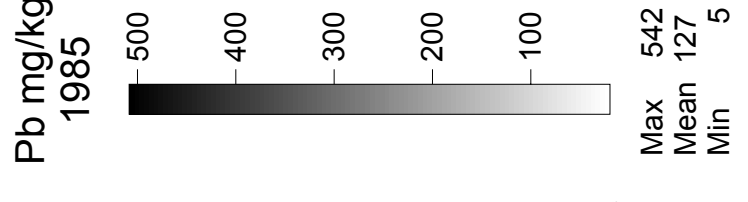

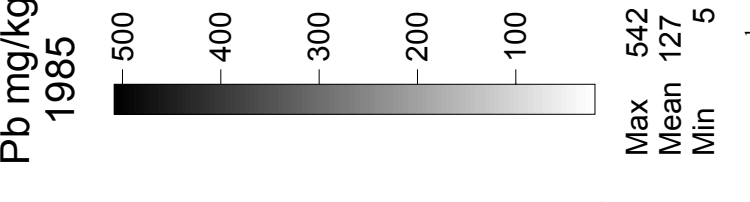

D)

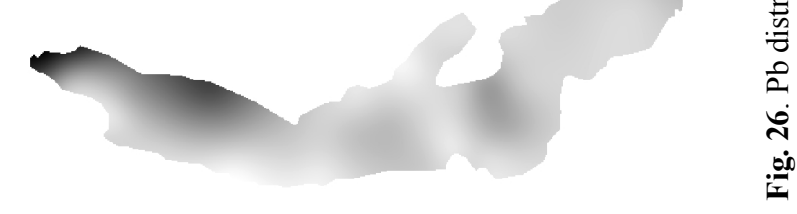

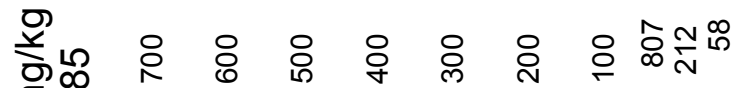
롱 N

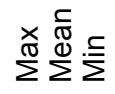

N 
In 1996, however, the distribution maps showed a completely different pattern, since the most contaminated areas were located in the Southern region of Lake Orta, the shallowest area of the lake. This distribution may be due in part to the fact that the liming treatment covered only $2 / 3$ of the lake surface, roughly from the southern tip to the end of the Central Basin, which is characterized by the $120 \mathrm{~m}$ deep platform described above. Copper and the other metallic elements showed an accumulation in the Northern part of the lake, suggesting that the same transport process controls the distribution of $\mathrm{Cr}, \mathrm{Pb}, \mathrm{Ni}, \mathrm{Zn}, \mathrm{Hg}$, and Cd (Figs 25-29). In 1996 the concentrations of trace metals still remained very high and potentially hazardous for the environment (Baudo et al. 1993; Baudo 1994).

The data for pore water are available only for copper and chromium. For the other metals, it is impossible to say whether these toxicants are effectively bioavailable (Tessier \& Campbell 1987), and the measured concentrations in the solid phase refer to all the organic and inorganic fractions, each of which is bioactive to a different degree.

For the 1985 samples, maps of distributions have been calculated also for $\mathrm{B}, \mathrm{V}, \mathrm{Sr}, \mathrm{Sn}, \mathrm{Mo}, \mathrm{Co}, \mathrm{Be}$, and Li (Figs 30-33). These elements very likely reflect geochemical inputs only, and in fact compare well with mean data for granite (Tab. 5; Bowen 1979). Co pres??ents concentrations 10 times higher than in granite, but still lower than the Canadian Soil Quality Guidelines, and probably does not reach harmful levels.

Tab. 5. Chemical composition $\left(\mathrm{mg} \mathrm{kg}^{-1}\right)$ of L. Orta sediments and reference values (Granite $=$ Mean granite, after Bowen 1979; SeQG = Canadian Sediment Quality Guidelines; PEL = Probable Effect Level; SoQG; Canadian Soil Quality Guidelines).

\begin{tabular}{lccccccc}
\hline & Min & Mean & Max & Granite & SeQG & PEL & SoQG \\
\hline $\mathrm{B}$ & 2.25 & 9.01 & 26.26 & 12 & & & 2 \\
$\mathrm{~V}$ & 12.52 & 65.79 & 122.45 & 72 & & & 130 \\
$\mathrm{Sr}$ & 5.56 & 30.98 & 57.68 & 285 & & & \\
$\mathrm{Sn}$ & 1.94 & 2.61 & 4.45 & 3.5 & & & 5 \\
$\mathrm{Mo}$ & 0.46 & 0.70 & 1.20 & 2 & & & 5 \\
$\mathrm{Co}$ & 2.97 & 10.56 & 20.40 & 1 & & & 40 \\
$\mathrm{Be}$ & 0.98 & 2.64 & 4.81 & 5 & & & 4 \\
$\mathrm{Li}$ & 16.22 & 47.00 & 78.33 & 30 & & & \\
$\mathrm{Cd}$ & 0.27 & 1.33 & 3.00 & 0.09 & 0.6 & 3.5 & 1.4 \\
$\mathrm{Hg}$ & 0.05 & 0.57 & 2.01 & 0.08 & 0.17 & 0.486 & 6.6 \\
\hline
\end{tabular}

$\mathrm{Cd}$ and $\mathrm{Hg}$ concentrations, on the other hand, are remarkably higher than in granite and even higher than the Canadian Sediment Quality Guidelines. However, even if $\mathrm{Cd}$ approaches the Canadian Soil Quality Guidelines, and $\mathrm{Hg}$ exceeds the Canadian Probable Effect Level for sediments, this does not means necessarily that these two elements constitute a hazard for the biota. In fact, probably they are present into the sediment as a results of the weathering of the drainage basin (no sources of pollutants are known); therefore, their bioavailability could be low enough to prevent harmful effects.

\subsection{Mobile elements}

Mobile elements are those that can easily change redox status and solubility, hence precipitating or dissolving when the physico-chemical conditions at the water-sediment interface change (Tab. 6).

For iron, sulphur and manganese the maps of distribution (Figs 34-36) clearly indicate an increase in concentration. This is confirmed by the data of the cores collected in 1992, showing that the surficial layers were enriched with respect to the background values, probably for a reduction or elimination of mineralisation of the organic matter, with a consequent accumulation of insoluble forms of these elements. It should be noted that large amounts of sulphates were discharged by industrial sources since the rayon factory effluents carried copper in the sulphate form (Calderoni \& de Bernardi 1992).

In pore water from the cores, sulphates are in fact increasing toward the upper portions as the equilibrium between liquid and solid fraction shifts in response to the enhanced sedimentation of sulphur.

The third mobile element, manganese (Fig. 36), displays a somewhat different behaviour. Mn concentrations decreased severely from 1985 to 1992, and further between 1992 and 1996. Obviously, the new conditions created at the water-sediment interface favours more soluble forms of this elements.

\section{CONCLUSIONS}

The low sedimentation rate of L. Orta $\left(2 \mathrm{~mm} \mathrm{y}^{-1}\right.$, Corbella et al. 1958, Adams et al. 1978, $4.5 \mathrm{~mm} \mathrm{y}^{-1}$, Provini \& Gaggino 1985), suggests that the surficial layer $(2 \mathrm{~cm})$ collected in 1996 should represent the material settled after the liming. Sampling in 1996 was repeated at exactly the same stations as in 1985, and the comparison between the two sampling events should thus reflect the changes in the sediment composition due to the liming and the subsequent evolution of the lake.

The pre- and post-liming comparison clearly shows that the treatment modified the water chemistry decreasing the dissolved metal concentrations (Camusso et al. 1992) and resulting in deposition of a large portion of these elements. Figure 37 clearly demonstrates that the lime treatment removed pollutants from the water column, effecting a marked increase in the concentrations of most of the contaminants of interest. These increases are especially significant for all the metallic elements, which are far less soluble at the near neutral $\mathrm{pH}$ of the water. $\mathrm{Ca}$ also increased by 34 times because the contents of this element in the limestone used for the liming largely exceed the geochemical load of the tributaries. 


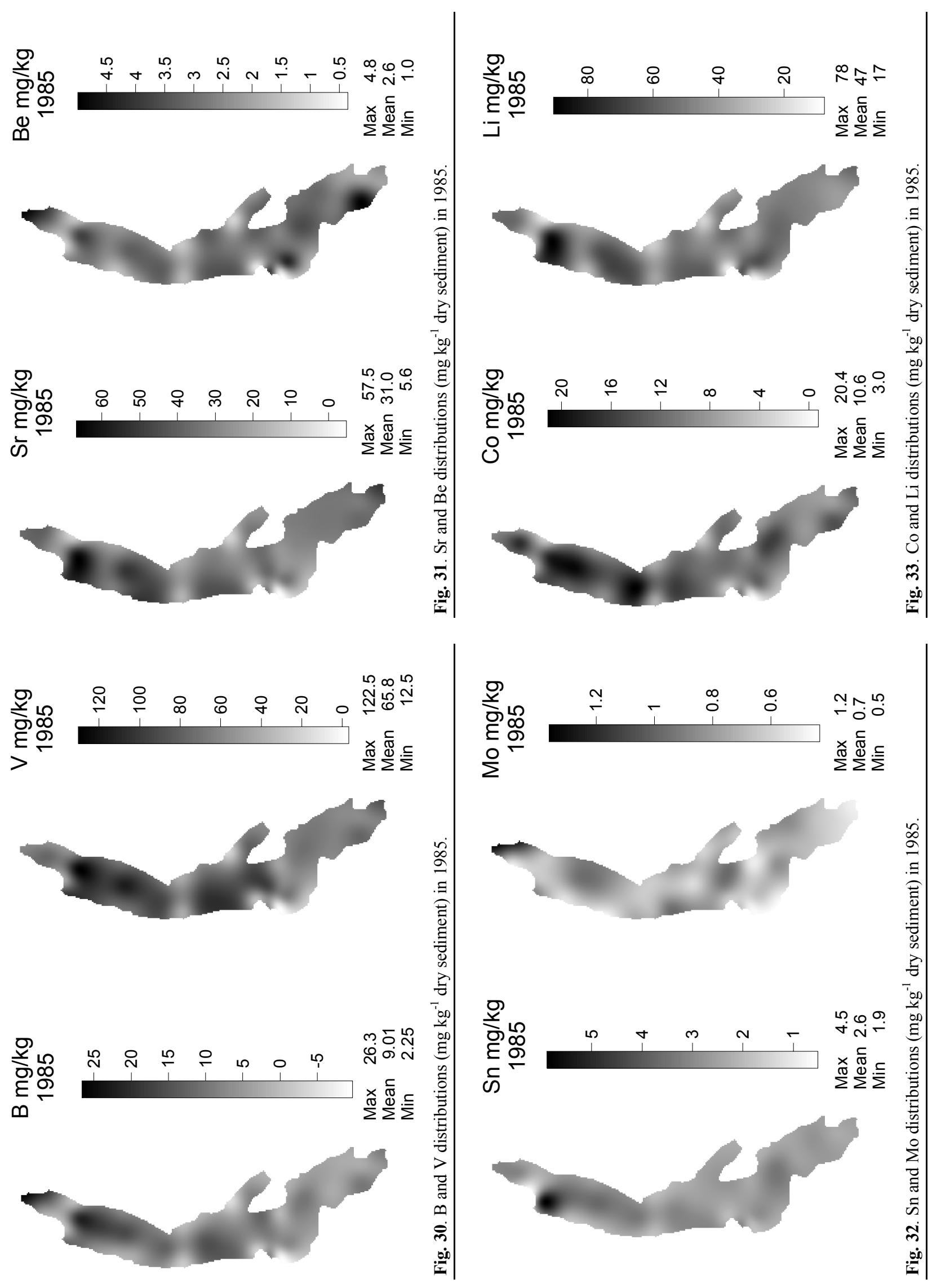


Tab. 6. Mobile elements in Lake Orta sediments.

$\underline{\text { Surficial sediment }}$

\begin{tabular}{|c|c|c|c|c|c|c|c|c|c|}
\hline & \multicolumn{3}{|c|}{1985} & \multicolumn{3}{|c|}{1992} & \multicolumn{3}{|c|}{1996} \\
\hline & Mean & $\min$ & Max & Mean & $\min$ & Max & Mean & $\min$ & Max \\
\hline $\mathrm{Fe} \%$ & 4.55 & 0.68 & 9.13 & 5.70 & 3.32 & 7.73 & 5.51 & 2.83 & 8.95 \\
\hline S \% & 0.18 & 0.01 & 1.20 & 0.44 & 0.05 & 1.15 & 0.56 & 0.07 & 1.79 \\
\hline $\operatorname{Mn}\left(\mathrm{mg} \mathrm{kg}^{-1}\right)$ & 641 & 149 & 6802 & 588 & 351 & 1205 & 570 & 259 & 1767 \\
\hline
\end{tabular}

Sediment cores

\begin{tabular}{ccccc}
\hline Station & Section & Fe & S & Mn \\
\hline 51 & $0-10$ & 7.69 & 0.83 & 479 \\
& $10-20$ & 8.25 & 0.27 & 472 \\
& $20-38$ & 6.57 & 0.09 & 529 \\
& $38-48$ & 6.33 & 0.05 & 593 \\
& $87-104$ & 4.16 & 0.05 & 417 \\
45 & $0-10$ & 7.73 & 0.06 & 1205 \\
& $10-20$ & 8.29 & 0.10 & 1483 \\
& $32-42$ & 7.45 & 0.06 & 1138 \\
13 & $0-10$ & 6.61 & 0.21 & 587 \\
& $10-20$ & 5.49 & 0.05 & 855 \\
& $50-60$ & 4.76 & 0.05 & 830 \\
\hline
\end{tabular}

Pore water $\left(\mathrm{mg} \mathrm{l}^{-1}\right)$

\begin{tabular}{llcl}
\hline Sample & Type & Section & $\mathrm{SO}_{4}$ \\
\hline 56 & Grab & & 0.20 \\
54 & Grab & & 2.00 \\
53 & Grab & & 1.40 \\
52 & Grab & & 0.60 \\
43 & Grab & & 0.10 \\
32 & Grab & & 0.60 \\
1 & Grab & $0-10$ & 8.40 \\
51 & Core & $10-20$ & 2.10 \\
& & $38-48$ & 0.90 \\
& & $0-10$ & 2.20 \\
45 & Core & $10-20$ & 1.50 \\
& & $32-42$ & 0.50 \\
& & $0-10$ & 3.20 \\
13 & Core & $10-20$ & 1.60 \\
& & $50-60$ & 0.50 \\
\hline
\end{tabular}

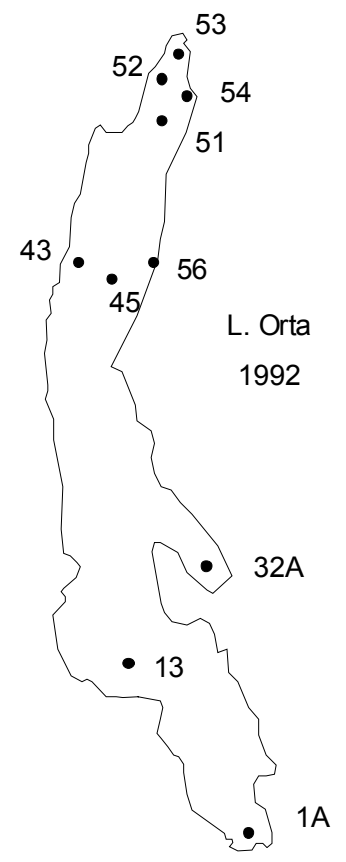



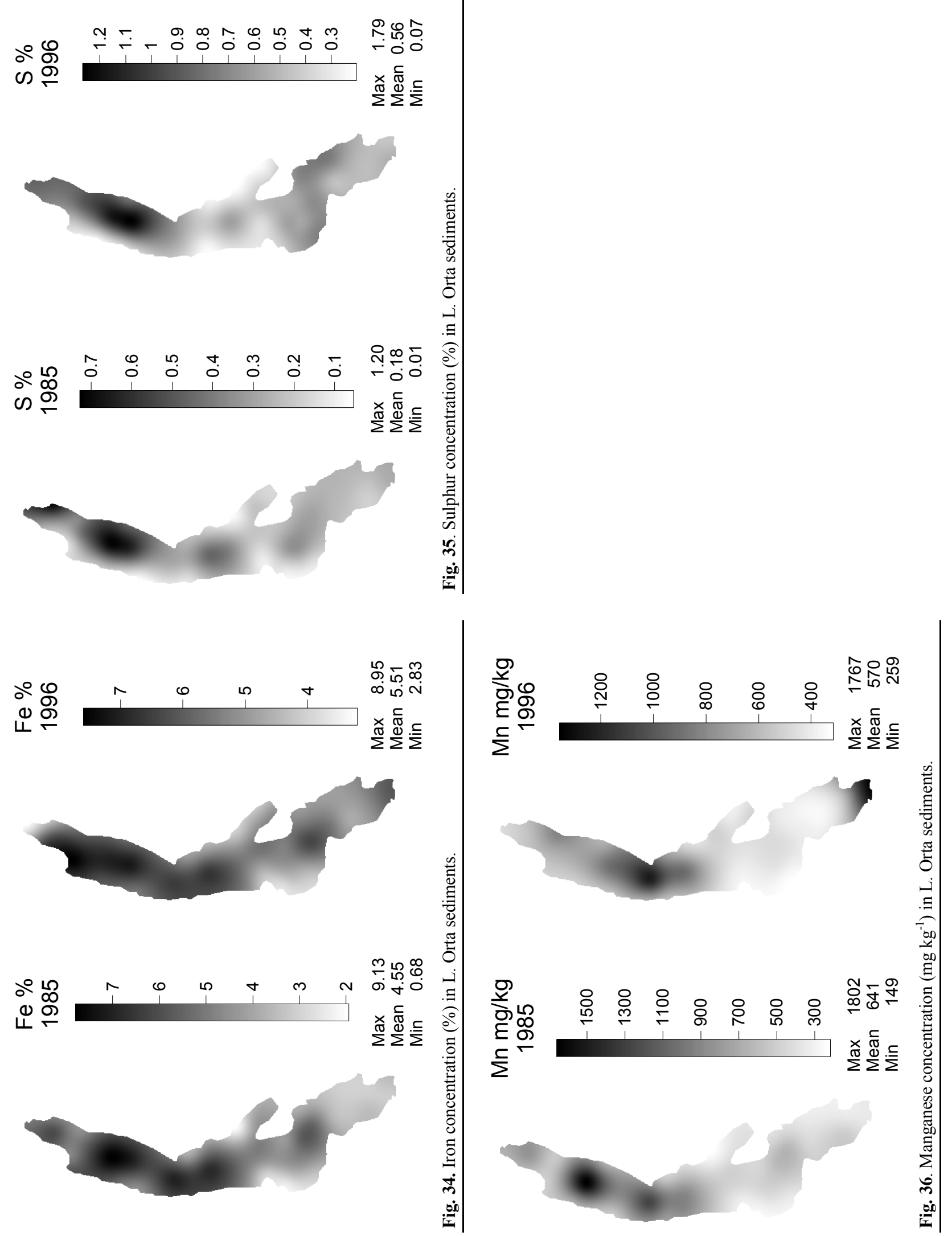


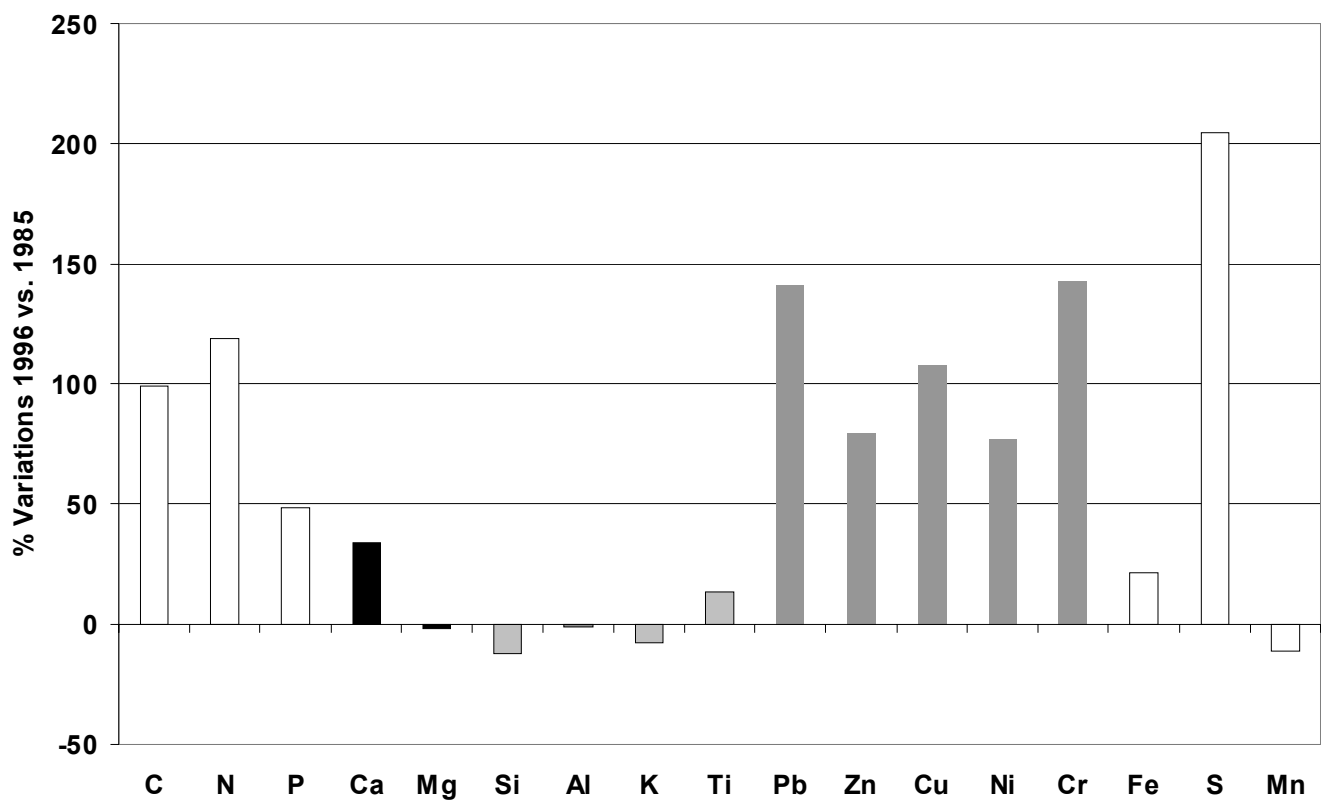

Fig. 37. Variation between 1985 and 1996 in the chemical composition of L. Orta sediments.

Concentrations in the upper $2 \mathrm{~cm}$ of sediments decrease only for $\mathrm{Si}, \mathrm{Al}, \mathrm{K}$, and $\mathrm{Mg}$. These decreases most likely reflect a "diluting" effect due to both the limestone addition and the enhanced deposition of autochthonous organic matter (mostly plankton remains), resulting from the algal blooms favoured by the restoration of the lake conditions. Finally, the "mobile" elements $\mathrm{Fe}$ and $\mathrm{S}$ are precipitated at a greater rate, while Mn seems to become more soluble in the new conditions created by the liming. The sediment chemical composition of this environment would still be classified as "heavily contaminated", according to the ranking proposed by the US Environment Protection Agency (Giesy \& Hoke 1990). The cluster analysis (Figs 38-39) clearly shows that the liming affected the sediment chemical composition changing the relationships between elements, as a result of the cleaning of the water column by the sedimenting calcium carbonate and plankton material.

Because of the relatively low sedimentation rate of this lake, it will be some time before the contaminated layer of the sediments will be buried and will no longer interact with the overlying water column. Considering the high concentration in the solid phase and the equilibrium established between sediment and pore water, the concentration gradient should produce a back diffusion of the contaminants from the sediment to the overlying water for the indeterminable future. The possible toxic effect of the sediment is obviously mediated by the partitioning between solid and liquid phase, and particularly by the concentrations in pore water.

For copper, there is a statistically significant correlation between the concentration in sediments and that of pore water, indicating that for a large part of the lake the benthic environment is facing very high concentrations of dissolved copper. However, these measures indicate only the content of the total dissolved copper, and we have no indication of the degree of the truly bioavailable fraction. It is therefore impossible to conclude that the concentrations in pore water are actually in the toxic range. For instance, a large fraction of the metal could be bound to organic substances; in fact, the sediments have an average concentration of $3.55 \%$ of organic carbon. In addition, the $\mathrm{pH}$ of pore water is around 6.5, which would precipitate copper as hydroxide or coprecipitate it with iron, aluminium and manganese hydroxides.

For chromium, the increase in pore water with the increase in the solid phase is even more relevant. As with copper, $\mathrm{Cr}$ is present in far higher concentrations than what might be considered safe for the biota, but again no data about its actual bioavailability are available. It is interesting to note that the concentration of copper in pore water is related not only to the concentration of the metal in sediments, but also to those of silicium, calcium and iron, confirming that the particle composition is quite active in controlling the partitioning between solid and dissolved phases. In addition, lead seems to be in competition with copper for the binding sites on particles and on the ligands in pore waters.

The change induced by the liming had a direct effect on the sediment and pore water composition, but the chemical equilibrium in the sedimentary environments is rather different from that of the water column. 


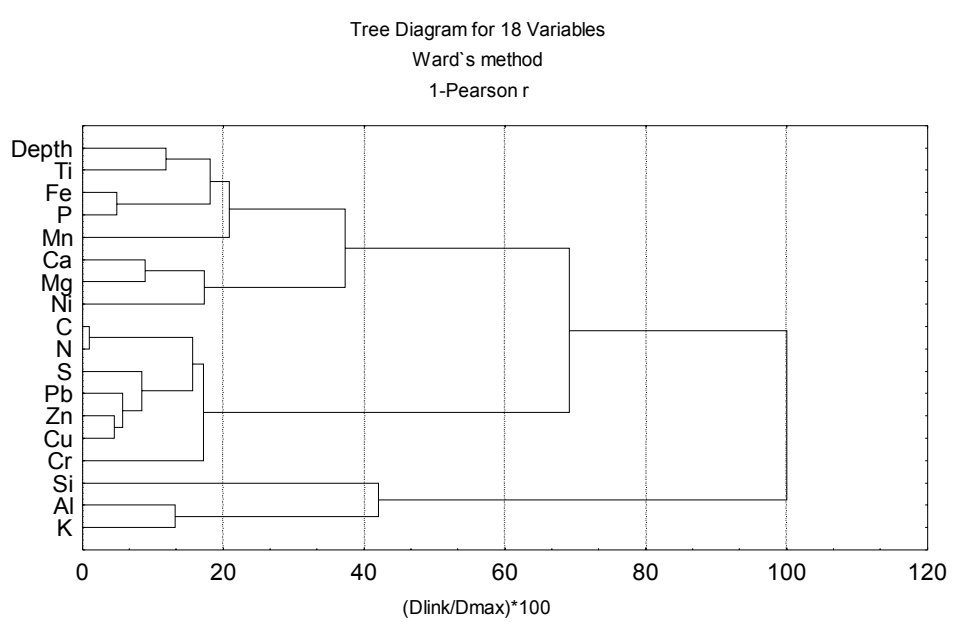

Fig. 38. Cluster data 1985.

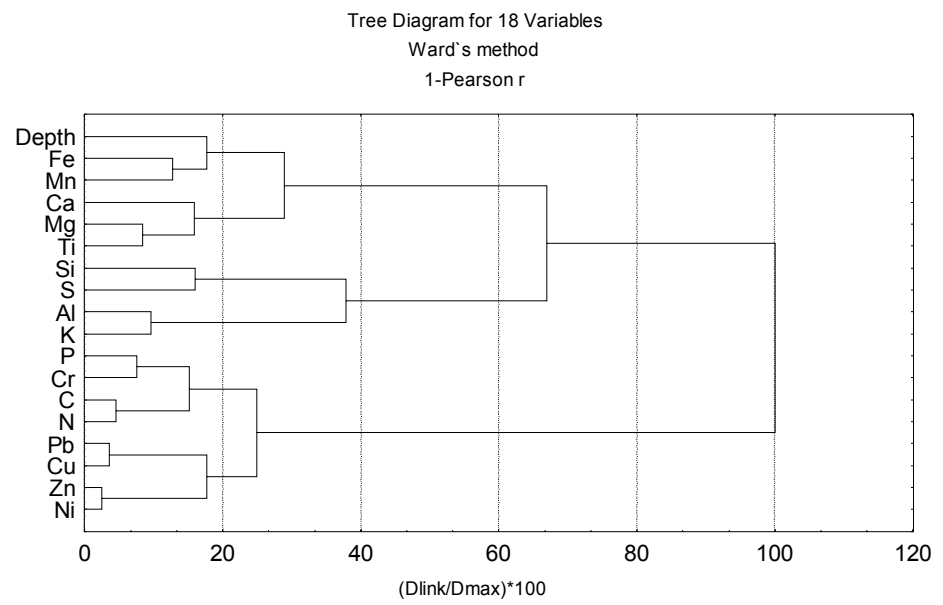

Fig. 39. Cluster data 1996.

For chromium, the partitioning between solid and liquid phases is controlled by $\mathrm{Si}, \mathrm{Fe}$ and $\mathrm{K}$, suggesting that the binding sites could be different from those of copper. In this case, zinc and nickel seem to compete with chromium, since they are inversely correlated. On the basis of this relationship, it can be estimated that the average concentrations in pore water from the first 10 $\mathrm{cm}$ of sediments should be no lower than $120 \mu \mathrm{g} \mathrm{l}^{-1}$ for copper, and $190 \mu \mathrm{g}^{-1}$ for chromium. These figures are relatively high compared to the average values for the water column (20 and $2 \mu \mathrm{g} \mathrm{l}^{-1}$ respectively for $\mathrm{Cu}$ and $\mathrm{Cr}$ ), suggesting that a high degree of exchange of these metals between water and sediments will be present.

The bottom deposits, having acted for years as a trap for metallic elements and nutrients, could now become an internal source and delay the recovery, at least for the benthic community. Pore water concentrations largely exceed the thresholds for aquatic organisms (Giesy \& Hoke 1990), at least in the case of chromium, copper, and ammonia (1992 data).
In conclusion, it seems likely that the metal concentrations in both sediments and pore water could be high enough to have a potentially toxic effect on the biota. The concentration of ammonia is also very high, and may likewise contribute to toxicity.

\section{REFERENCES}

Adams, M.S., P. Guilizzoni \& S. Adams. 1978. Sedimentary pigments and recent primary productivity in Northern Italian Lakes. Mem. Ist. ital. Idrobiol., 36: 267-285.

Ballaré, G., E. Bielli, G. Fornara \& P. Masseroni. 1992. Qualità e utilizzi delle acque litorali del Lago d'Orta. Documenta Ist. Ital. Idrobiol., 38: 83-94.

Barbanti, L., C. Bonacina, G. Bonomi \& D. Ruggiu. 1972. Lago d'Orta: situazione attuale e previsioni sulla sua evoluzione in base ad alcune ipotesi di intervento. Ed. Ist. Ital. Idrobiol., Pallanza: 113 pp.

Baudo, R. 1989. Uncertainty in description of sediment chemical composition. Hydrobiologia, 176/177: 441-448.

Baudo, R. 1990. Sediment Sampling, Mapping, and Data Analysis. In: R. Baudo, J.P. Giesy \& H. Muntau (Eds), Sediments: Chemistry and Toxicity of In-Place Pollutants. Lewis, Chelsea, MI: 15-60. 
Baudo, R. 1994. Chimica dei sedimenti del Lago d'Orta. Sottotesi di Laurea, Univ. di Milano: $50 \mathrm{pp}$.

Baudo, R., L. Amantini, F. Bo, R. Cenci, P. Hannaert, A. Lattanzio, G. Marengo \& H. Muntau. 1989. Spatial distribution patterns of metals in the surface sediments of Lake Orta (Italy). Sci. Total Env., 87/88: 117-128.

Baudo, R., G.A. Tartari, A. Lami, P. Ross, F. Bo, R. Cenci, R. Vivian \& H. Muntau. 1993. Ecological risk of in-situ contaminants in Lake Orta. 14th Annual Meeting SETAC Ecological Risk Assessment: Lessons Learned? Houston, TX, USA, 14-18 November 1993. Abstract Book: 141.

Baudo, R., P. Ross \& L. Guzzella. 1996. Liming as a remedial action for an industrially polluted lake (Lake Orta, Northern Italy). In: M. Munawar \& G. Dave (Eds), Development and Progress in Sediment Quality Assessment: Rationale, Challenges, Techniques \& Strategies. Ecovision World Monograph Series, SPB Academic Publishing, Amsterdam: 177-193.

Bonacina, C. 1970. Il Lago d'Orta: ulteriore evoluzione della situazione chimica e della struttura della biocenosi planctonica. Mem. Ist. Ital. Idrobiol., 26: 141-204.

Bonacina, C. \& G. Bonomi. 1984. I grandiosi effetti ambientali determinati dalle prime fasi del disinquinamento del Lago d'Orta. Documenta Ist. ital. Idrobiol., 2: 1-24.

Bonacina, C., G. Bonomi \& C. Monti. 1986. Oligochaete cocoon remains as evidence of past lake pollution. Hydrobiologia, 143: 395-400.

Bonacina, C., A. Calderoni \& R. Mosello. 1988. Il Lago d'Orta: evoluzione dell'inquinamento e interventi diretti al recupero di uno dei più grandi laghi acidi del mondo. $A c$ qua Aria, 1/88: 69-74.

Bonacina, C., G. Bonomi, A. Calderoni \& R. Mosello. 1987. Il Lago d'Orta: evoluzione dell'inquinamento ed interventi diretti al recupero di uno dei più grandi laghi acidi del mondo. Atti Simposio "Deposizioni acide: un problema per acque e foreste". Documenta Ist. Ital. Idrobiol., 14: 197-213.

Bonacina, C., G. Bonomi, L. Barbanti, R. Mosello, D. Ruggiu \& G.A. Tartari. 1988a. Lake Orta (N. Italy): recovery after the adoption of restoration plans. In: N.W. Schmidtke (Ed.), Toxic contamination in Large Lakes. Impact of Toxic Contaminants on Fisheries Management. Lewis Publishers: 101-130.

Bonacina, C., G. Bonomi, L. Barbanti, R. Mosello \& D. Ruggiu. 1988b. Recovery of an industrially acidified, ammonium and heavy metals polluted lake (Lake Orta, N. Italy), due to the adoption of treatment plants. Verh. int. Ver. Limnol., 23: 535-544.

Borchardt, G. \& J. Butler. 1957. Determination of trace amounts of copper. Anal. Chem., 28: 414-419.

Boriani, A. \& R. Sacchi. 1974. The "Insubric" and other tectonic lines in the southern Alps (NW Italy). Mem. Soc. Geol. It., 13: 1-11.

Bowen, H.J.M. 1979. Environmental Chemistry of the Elements. Academic Press: 333 pp.

Buysman, E., J.F.M. Maas \& W.H.M. Asman. 1985. Ammonia emission in Europe. Inst. Meteorology and Oceanography, Sate Univ. Utrecht, The Netherlands. Report R-85-2: 28 pp.

Cairns, J., Jr., A.V. Nebeker, J.H. Gakstatter \& W. Griffis. 1984. Toxicity of copper-spiked sediments to freshwater invertebrates. Environ. Toxicol. Chem., 3: 435-446.

Calamari, D. \& R. Marchetti. 1975. Predicted and observed acute toxicity of copper and ammonia to rainbow trout (Salmo gairdneri Rich.). Progr. Wat. Tech., 7:569

Calderoni, A. \& R. Mosello. 1990. Evoluzione delle caratteristiche chimiche del Lago d'Orta nel quadriennio Febbraio 1984-Febbraio 1988. Documenta Ist. ital. Idrobiol., 28: 71-87.
Calderoni, A. \& R. de Bernardi. 1992. Le vicende del Lago d'Orta dal degrado al recupero. Documenta Ist. ital. Idrobiol., 38: 1-23.

Calderoni, A., R. de Bernardi \& R. Mosello. 1990. Proposta di risanamento del Lago d'Orta tramite liming. Documenta Ist. ital. Idrobiol., 28: 117-131.

Calderoni, A., R. Mosello \& A. Quirci. 1991. Chemical response of Lake Orta (Northern Italy) to liming. Arch. Hydrobiol., 122: 421-439.

Calderoni, A., R. Mosello \& D. Ruggiu. 1992. Sixty years of limnology on Lago d'Orta: a case history of recovery from heavy pollution. Mem. Ist. ital. Idrobiol., 50: 201-223.

Camusso, M. \& G. Tartari. 1991a. Liming effects on trace metal distribution and sedimentation in acidic lake $(\mathrm{N}$. Italy). In: J.G. Farmer (Ed.), Proc. Int. Conf. "Heavy Metals in the Environment". Edimburg, 16-20 September. Vol. 2: 63-66.

Camusso, M., G. Tartari \& E. Cappelletti. 1989a. Seasonal trend of copper sedimentation in lake Orta (Northern Italy). Sci. Total Environ., 87/88: 59-75.

Camusso, M., G. Tartari \& A. Zirino. 1989b. Profiles of copper ion activity in the lake Orta, Italy. In: J.P. Vernet (Ed.), Proc. Int. Conf. "Heavy Metals in the Environment". Geneva, 12-15 September. Vol. 1: 226-229.

Camusso, M., G. Tartari \& A. Zirino. 1991c. Measurament and prediction of copper ion activity in lake Orta, Italy. Environ. Sci. Technol., 25: 678-683.

Camusso, M., G. Tartari, L. Previtali \& A. Zirino. 1991b. Regulatory mechanisms and behaviour of copper in an industrially-polluted acidic lake in Northern Italy. Verh. int. Ver. Limnol., 24: 1035-1040.

Camusso, M., G. Tartari, M. Renoldi, P. Riva, R. Mosello, A. Calderoni, G.A. Tartari, A. Quirci, H. Muntau, G. Marengo, R. Cenci, B. Klüssendorf, A. Lattanzio, M. bianchi \& R. Vivian. 1992. Effetti dell'intervento di liming sulle concentrazioni dei metalli nelle acque lacustri. In: A. Calderoni \& R. de Bernardi (Eds), Atti Conv. "Orta, un lago da salvare: le fasi del suo recupero", Orta, 9-10 Aprile 1990. Documenta Ist. ital. Idrobiol, 38: 53-70.

Carollo, A. \& V. Libera. 1990. Idrologia del bacino idrografico del Lago d'Orta. Documenta Ist. ital. Idrobiol., 28: 38.

Chapman, P.M. 1987. Marine sediments toxicity tests. In: Symposium on Chemical and Biological Characterization of Sludges, Sediments, Dredge Spoils and Drilling Muds. American Society for Testing and Materials, Philadelphia, PA. ASTM STP 976: 391-402.

Chiaudani, G. 1969. Contenuto normali ed accumuli di rame in Phragmites communis L. come risposta a quelli nei sedimenti di sei laghi italiani. Mem. Ist. ital. Idrobiol., 25: 81-95.

Corbella, C., V. Tonolli \& L. Tonolli. 1958. I sedimenti del Lago d'Orta testimoni di una disastrosa polluzione cuproammoniacale. Mem. Ist. ital. Idrobiol., 10: 9-50.

Fogg, G.E. \& J.H. Belcher. 1961. Pigments from the bottom deposits of an English lake. New Phytol., 60: 129-142.

Gaggino, G.F. 1980. Mercurio nelle acque di irrigazione. Inquinamento, 22: 53-60.

Gerletti, M. \& A. Provini. 1978. Effect of nitrification in Orta Lake. Prog. Wat. Tech., 10: 839-851.

Giesy, J.P. \& R.A. Hoke. 1990. Freshwater Sediment Quality Criteria: Toxicity Bioassessment. In: R. Baudo, J.P. Giesy \& H. Muntau (Eds), Sediments: Chemistry and Toxicity of In-Place Pollutants. Lewis, Chelsea, MI: 265-348.

Giussani, G. 1990. La fauna ittica del Lago d'Orta. Documenta Ist. ital. Idrobiol., 28: 109-115.

Goldman, J.C. \& P.G. Brewer. 1980. Effect of nitrogen source and growth rate on microflora-mediated changes in alkalinity. Limnol. Oceanogr., 25: 352-357.

Guilizzoni, P. 1978. Ricostruzione temporale di livelli trofici in laghi di diversa tipologia attraverso lo studio dei sedi- 
menti. In: Atti del Convegno sulla eutrofizzazione in Italia. CNR, Roma, AC/2/56-1978: 197-207.

Guilizzoni, P. \& A. Lami. 1988. Sub-fossil pigments as a guide to the phytoplankton history of the acidified Lake Orta (N. Italy). Verh. int. Ver. Limnol., 23: 874-879.

Guilizzoni, P. \& A. Lami. 1990. Ricerche paleolimnologiche sul Lago d'Orta. In: C. Bonacina, A. Calderoni \& R. de Bernardi (Eds), Ricerche limnologiche sul Lago d'Orta finalizzate al suo risanamento. Documenta Ist. ital. Idrobiol., 28: 53-69.

Håkanson, L. \& M. Jansson. 1983. Principles of Lake Sedimentology. Springer-Verlag, Berlin Heidelberg, New York, Tokyo: $316 \mathrm{pp}$.

Jones, B.F. \& C.J. Bowser. 1978. The mineralogy and related chemistry of lake sediments. In: A. Lerman (Ed.), Lakes Chemistry Geology Physics. Springer-Verlag, New York:. 179-235.

Jones, R.A. \& G.F. Lee. 1978. Evaluation of the Elutriate Test as a Method of Predicting Contaminant Release During Open Water Disposal of Dredged Sediment and Environmental Impact of Open Water Dredged Material Disposal. Volume I: Discussion. U.S. Army Corps of Engineers, Waterways Experiment Station, Vicksburg, MS. Technical Report D78-45.

Julshamm, K. \& O.R. Braekkan. 1975. Determination of trace elements in fish tissues by the standard addition method. At. Absorption Newslett., 14: 49-52.

Kemp, A.L.W., R.L.Thomas, C.I. Dell \& J.-M. Jaquet. 1976. Cultural Impact on the Geochemistry of Sediments in Lake Erie. J. Fish. Res. Bd Can., 33: 440-462.

Knight, A.W. 1984. The evaluation of contaminated sediments employing selected benthic freshwater invertebrates. Final Report of the USEPA Cooperative Agreement No. CR808424. University of California, Davis, CA. USEPA, Environmental Research Laboratory, Corvallis, OR.

Koch, W. \& H. Malissa. 1957. Dosage précis du carbone au moyen d'un enrigestreur de conductivité. La Metallurgie, 89: 719-727.

Lacqua, P., V. Bignami \& G. Galbusera. 1983. Indagine chimica sulle acque reflue provenienti dalla rete fognaria dei comuni di San Maurizio d'Opaglio e Pella in entrata all'impianto di depurazione consortile di Lagna. Consorzio Depurazione Acque Reflue del Cusio. Rapporto tecnico: $10 \mathrm{pp}$.

Marengo, G. \& R. Baudo. 1988. Forme del fosforo nei sedimenti lacustri. Acqua Aria, 6/88: 717-721.

Metha, N.S., J.O. Legg, C.A.I. Goring \& C.A. Black. 1954 Detrmination of organic phosphorus in soild. I. Extraction method. Soil. Sci. Soc. Amer. Proc., 18: 443-449.

Monti, R. 1930. La graduale estinzione della vita nel Lago d'Orta. Rend. R. Ist. Lomb. Sc. Lett., 63: 3-22.

Mosello, R. \& A. Calderoni. 1990. Pollution and recovery of Lake Orta (Northern Italy). In: Baudo, R., J.P. Giesy \& H. Muntau (Eds), Sediments: chemistry and toxicity of inplace pollutants. Lewis Publishers: 349-363.

Mosello, R., R. Baudo \& G.A. Tartari. 1986a. Metal concentrations in a highly acidic lake: L. Orta (Northern Italy). Mem. Ist. ital. Idrobiol., 44: 73-96.

Mosello, R., C. Bonacina, A. Carollo, V. Libera \& G.A. Tartari. 1986b. Acidification due to in-lake ammonia oxidation: an attempt to quantify the proton production in a highly polluted subalpine Italian lake (Lake Orta). Mem. Ist. ital. Idrobiol., 44: 47-71.

Mosello, R., A. Calderoni \& G.A. Tartari. 1989. pH related variations of trace metal concentrations in L. Orta. Sci. Total Environ., 87/88: 255-268.

Murphy, J. \& J.P. Riley. 1962. A modified single-solution method for determination of phosphate in natural waters. Anal. Chim. Acta, 27: 31-36.
Nebeker, A.V. \& C.E. Miller. 1988. Use of the amphipod crustacean Hyalella azteca for freshwater and estuarine sediment toxicity tests. Environ. Toxicol. Chem., 7: 10271033.

Picotti, M. 1958. Ricerche nel Lago d'Orta. Boll. Pesca, Piscic. Idrobiol., 12: 126-158.

Picotti, M. \& G. Baldassi. 1941. Microanalyse des Kupfers und seine Bestimmung in einigen Gewässern und Wassertieren der Venetia Giulia. Mikrochem., 30: 77-110.

Premazzi, G. 1979. The Cs137 technique to evaluate recent sedimentation rates. In: R. Marchetti (Ed.), Convegno sulla Eutrofizzazione in Italia. CNR, Roma, AC/2/45-70: 181-196.

Premazzi, G. \& G. Parise. 1986. I fenomeni di compattazione nella geocronologia dei sedimenti lacustri. Acqua Aria, 8/86: 783-790.

Provini, A. \& G.F. Gaggino. 1986. Depth profiles of $\mathrm{Cu}, \mathrm{Cr}$, and $\mathrm{Zn}$ in Lake Orta sediments (Northern Italy). In: P.G. Sly (Ed.), Sediments and Water Interactions. Springer Verlag, Berlin: 167-174.

Provini, A., G. Premazzi, G.F. Gaggino \& G. Parise. 1987. Valutazione del rischio potenziale da metalli pesanti nei laghi mediante l'analisi dei sedimenti. Ing. Amb., 16: 6876

Raven, J.A. 1985. Regulation of $\mathrm{pH}$ and generation of osmolarity in vascular plants: a cost-benefit analysis in relation to efficiency of use of energy, nitrogen and water. Tansley Report No 2. New Phytol., 101: 25-77.

Robbins, J.A. \& D.N. Edgington. 1975. Detrmination of recent sedimentation rates in Lake Michigan using $\mathrm{Pb}-210$ and Cs-137. Geochim. Cosmochim. Acta, 39: 285-304.

Ruess, J.O. 1975. Chemical/biological relationships relevant to ecological effects of acid rainfall. US EPA 660/3-75032: $46 \mathrm{pp}$.

Salomons, W., N.M. de Rooij, H. Kerdijk \& J. Bril. 1987. Sediments as a source for contaminants. Hydrobiologia, 149: 13-30.

Scheiner, D. 1976. Determination of ammonia Kjeldhal nitrogen by indophenol method. Wat. Res., 10: 31-36.

Tessier, A. \& P.G.C. Campbell. 1987. Partitioning of trace metals in sediments: relationships with bioavailability. Hydrobiologia, 149: 43-52.

Tondina, A. 1992. Studi sulla dinamica del fitoplancton del Lago d'Orta in relazione ad un grande intervento di liming. Tesi di Dottorato di Ricerca in Scienza dell'Ambiente, Univ. Studi Parma: 358 pp.

Tonolli, V. \& R.A. Vollenweider. 1961a. Rapporto sulle ricerche eseguite sul Lago d'Orta nel periodo dal 1959 al 1961. Pallanza, Ottobre 1961: 18 pp.

Tonolli, V. \& R.A. Vollenweider. 1961b. Le vicende del Lago d'Orta inquinato da scarichi cupro-ammoniacali. In: Atti Convegno Acque di Scarico Industriali, Milano, 4-7 Aprile 1960: 99-109.

Trevisan, M. 1992. Ricostruzione dell'evoluzione trofica e della contaminazione di tre grandi laghi subalpini (Maggiore, Orta e Lugano) attraverso la caratterizzazione dei sedimenti. Tesi di Laurea, Univ. Milano: 336 pp.

Vallentyne, J.R. 1955. Sedimentary chlorophyll determination as a paleobotanical method. Can. J. Bot., 33: 304-313.

van Breemen, N., C.T. Driscoll \& J. Mulder. 1986. Acidic deposition and internal proton sources in acidification of soils and waters. Nature, 307: 599-604.

Vogler, P. 1965. Phosphatanalytic in der Limnologie. II. Die Bestimmung des Gelösenen - Phosphates. Fortsch. Wasserchemie und Ihrer Grenzgebeite, 2: 109-119.

Vollenweider, R.A. 1963. Studi sulla situazione attuale del regime chimico e biologico del Lago d'Orta. Mem. Ist. ital. Idrobiol., 16: 21-125. 